\title{
The Impact of Individual Motivations and Social Capital on the Continuous Usage Intention of Mobile Social Apps
}

\author{
Sangjae Lee ${ }^{1, *(1)}$ and Byung Gon Kim ${ }^{2}$ \\ 1 College of Business Administration, Sejong University, Seoul 05006, Korea \\ 2 Department of Business Administration, Namseoul University, Cheonan 31020, Korea; bgkim@nsu.ac.kr \\ * Correspondence: sangjae@sejong.ac.kr
}

Received: 13 August 2020; Accepted: 9 October 2020; Published: 12 October 2020

\begin{abstract}
Mobile social apps have experienced enormous growth as online personal networking media. Social exchange theory (for individual motivation), theories of collective action and social capital theory (for social capital) can be applied in order to understand how an individual's behavior may exert effects on or receive influences from other users with regard to the continuance usage intention of mobile social apps. This study examines individual motivations and social capital affecting relationship quality in terms of trust in and satisfaction with mobile social apps and how these factors influence continuance usage intentions of mobile social apps. An online survey is used to collect 320 responses from users of mobile social apps. Our results indicate that promotional motivation and innovativeness affect relationship quality levels. Maintaining relational enhancement, social homogeneity, and social identity along with service usefulness have effects on the relationship quality level, which in turn affects continuance usage intention. Given the lack of studies regarding the application of the theories of collective action and social capital to gain a better understanding of continuance usage intentions, this study provides additional insight into how individual motivations and social capital affect continuous usage.
\end{abstract}

Keywords: mobile social apps; individual motivations; social capital; relationship quality; attitude toward use of social apps; the continuance usage intention of social apps

\section{Introduction}

Mobile social apps have witnessed a rapid increase in the number of users around the world. Social apps offer a method by which to build and share social network. As of the second quarter of 2020, Facebook had 2.7 billion monthly active users who have accessed Facebook in the last month [1]. When employees form networks of positive relationships, they tend to share information and positive emotions more, benefiting individuals and their organizations [2].

Despite the fact that maintaining the continued usage of a social network service (SNS) can have strategic importance, major social network services are showing a slowdown in terms of the number of users [3]. Given the decreased numbers of revisiting users, research that investigates the key factors that influence continuance usage intention is crucial to those who devise marketing strategies for mobile social apps. Mobile social apps are mobile versions of desktop social applications installed on mobile devices such as smart phones and iPads, providing much more business importance than desktop applications as the reliance of business activities on smart devices increases. The sustainable use of mobile social apps becomes important as business processes based on smart devices become important in creating business value. Thus, sustainability issues can be applied in developing factors affecting the continuous usage of social apps. 
The research motivation behind this study can be described as follows. First, our study intends to focus on the effects of individual motivations (promotional motivation, altruism, innovativeness, and conformity) on relationship quality and continuance usage intention. Previous studies of utilitarian or hedonic motivations behind the use of mobile social apps are rather limited in that they focused on perceived value based on information and service quality levels, i.e., fun. However, it is necessary to examine additional facets of motivation based on social exchange theory [4] or social influence while including specific variables related to individual motivations toward participating in a social community.

Previous studies examined SNS qualities [5], gratifications [6], flow [7], and the research field itself, but investigations of the effects of individual motivations toward participating in a social community based on social exchange theory on relationship quality encompassing trust and satisfaction as they pertain to continuous usage are necessary. This study intends to fill this void. The difference in our approach is that we adopt a second-order construct to measure relationship quality, encompassing the two inherent variables of trust and satisfaction and testing the effects of four variables regarding individual motivations on relationship quality. Previous studies rarely considered the effects on relationship quality as a second-order construct encompassing trust and satisfaction.

Second, our study examines the role of social capital (maintaining relational enhancements, social homogeneity, social identity, and a social presence) with regard to continuance usage intention. Social capital, as a metaphor, refers to the advantages obtained by individuals from being in certain types of social arrangements or a positive product of human interaction [8]. It is facilitated by the use of the Internet [9] and has potential value because it offers an opportunity for actors to access information resources in a SNS [10], to engage in knowledge sharing behavior in an online community [11], and to build trust and affinity for brands [12]. Moreover, it is being applied toward more specific aspects and mechanisms after undergoing a maturation period [13]. Social capital can also expire through under-use and social media users are constantly searching for the next new feature [14]; this can be related to social media success [15], and the users with weak social capital are likely to less use social media as they have not accomplished the intended goal of social media to increase social capital [16-19]. As the pace and power of social media are having a major impact worldwide on expanding networks [20,21], it is necessary to study the impact of social capital of social media on its continuous usage in order to verify the role of social capital from social media empirically with regard to attracting users. In order to explain participation in online communities, electronic networks for practice, and social virtual world services, theories of collective action have been applied to study how social capital affects collaboration, the contribution of knowledge, and continuous usage intention [22,23]. In the context of mobile social apps, however, while it is necessary to apply theories of collective action and social capital in order to understand how users' social behaviors can affect or be influenced by other actors, studies applying these theories to understand continuance usage intention are almost nonexistent. While many studies have considered factors affecting trust and satisfaction [24,25], studies regarding the impact of social capital on relationship quality encompassing trust in and satisfaction with mobile social apps are rare. This study seeks to bridge this gap by suggesting four variables related to social capital: maintaining relational enhancement, social homogeneity, social identity, and social presence, all of which are posited to have an impact on relationship quality and the continuance usage intention of mobile social apps.

The next section presents the theoretical background on individual motivations and social capital, service usefulness, and relationship quality, and this is followed by explanations of the method of using the online survey, results based on a structural equation modeling analysis, a discussion, and a conclusion and implications for research and practice. 


\section{Literature Review}

\subsection{Individual Motivations and Social Capital for Adopting Mobile Social Apps}

Based previous literature on the continuous usage of SNS, our study suggests the factors affecting the sustainable use of mobile social apps which are showing much more business importance than desktop applications as business processes using smart devices become crucial in building business value. Thus, sustainability issues in continuous usage of social media [26-30] can be utilized in showing factors influencing the continuous usage of social apps.

Studies of SNSs have used motivational theory, flow theory, and trust theory [31-33], all of which are related to each other. Lin and $\mathrm{Lu}$ [32] adopted motivational theory and network externality to study user the use of a SNS. Individual motivations are important in the early stage of trust, when users do not have experience interacting with others [34]. Individual types of motivation such as those related to reputation and altruism exert a positive influence on the quality and quantity of knowledge sharing behavior [11]. Motivation can be used to classify SNS users, implying that motivation is an important factor describing SNS usage behaviors [35]. Individual motivations can be explained either as utilitarian motivation, which is based on functional, economic or extrinsic criteria, or as hedonic motivation, based on non-functional, emotional or intrinsic criteria [36]. SNS users' motivations can be utilitarian as users' trust and flow experiences are affected by information quality and system quality levels [31]. Information, systems, and service quality levels are related to functional criteria by which SNS users assess and evaluate whether a SNS will permit them to accomplish their objectives [5]. SNS users' motivations can be hedonic, as empathy and entertainment are crucial for flow and relationship quality outcomes [5]. For instance, pleasure is considered as a perceived value of SNSs related to enjoyment and entertainment obtained from SNS usage [37]. Pleasure and enjoyment will likely build positive emotional reactions toward SNSs by increasing satisfaction and a feeling of belonging with the SNS.

Previous studies of utilitarian or hedonic motivations for SNSs, however, are quite limited in that they focused on perceived value based on information and service quality levels, pleasure, and entertainment. Accordingly, it is necessary to study another aspect of motivation based on social exchange theory [4] or social influence while including specific variables related to individuation motivations toward participating in a social community. Social exchange theory posits that individuals adjust their interaction with others after comparing the cost and benefits of interactions [4]. Individuals contribute knowledge if they believe that the benefits outweigh the cost.

Social capital is not same as other type of capital, as it is positioned in relationships among individuals, while other types of capital are determined by assets [38]. Social influence represents the degree to which an individual's beliefs and attitudes are under the influence of referent other people [39]. Recently, social influence has also been posited to have an influence on SNS user behavior. For instance, $\mathrm{Ku}$ et al. [40] used gratifications theory and discovered that subjective norms play a positive role in the continuance usage intention of SNS users. Subjective norms and group norms have effects on teenagers' SNS usage [41].

Social capital is specifically described as "resources embedded in a social structure that are accessed and/or mobilized in purposive action" [42] (p. 29). The concepts of social capital have been utilized in order to provide insightful explanations for pro-social behaviors such as differential social achievements, community participation, and collective action, where the concept of individual-based capital such as financial or human capital cannot serve to provide an explanation [43]. Social capital is a determinant of intellectual capital, which can help firms create professional B2B services [44], and of the quality and quantity of knowledge sharing behavior in online community [11].

Social capital can diminish through under-use, and social media users are always searching for the next new feature [14], and can be associated with social media success [15]. Users with weak social capital tend to use social media less, as they have not obtained the intended goal of social media, i.e., to increase social capital $[16,17,19]$. As the pace and power of social sites are having a worldwide crucial impact on expanding networks or searching for information such as job opportunities [21], it is 
becoming important to examine the influence of social capital as built by social media on its continuous usage in order to investigate the role of social capital empirically using social media and how it accumulates users. While many studies have investigated factors affecting trust and satisfaction [24,25], studies of the effect of social capital on relationship quality in terms of trust in and satisfaction with mobile social apps are almost nonexistent. Thus, in the context of mobile social apps, it is necessary to introduce the theory of collective action and social capital in order to explain why individuals contribute time, effort, opinions, information, and knowledge for a collective group benefit, while they could simply watch and not provide any opinions or information. For instance, when a user's friends suggest that they should use a certain mobile social app platform, they are likely to abide by such a recommendation. While there exist negative effects resulting from social capital [45], theories of collective action improve our understanding of why individuals in a group would not merely watch and would rather participate by interacting with others and providing opinions and information to others owing to the influence of social capital [38].

Social competence or relational efficacy is the belief in the individual capability to create relationships with others in a community, and it affects behaviors when building relationships [46] or creating employee innovation [47]. With greater relational efficacy, individuals will perceive more value in relationships with others in a SNS and participate in more frequent interactions with others, increasing the continuous usage of mobile social apps. Social competence facilitates social acceptance, as it is not possible to participate in mobile social apps without being recognized by others who are requester of social competence when one can always ignore or reject the request.

Social capital involves maintaining relational enhancement, social homogeneity, social identity, and social presence. Social acceptance is crucial in SNSs, as further participation or satisfaction with the SNS cannot be successful if many users are allowed easy connections and have less interest in other users [48]. In this context, maintaining relational enhancement is crucial for the intention to engage in the continuous usage of mobile social apps, which will increase the attachment to the group and its members and the intention to share knowledge with others.

Social homogeneity refers to the extent to which individuals belong to a social group, accompanied by the emotional and social values possessed by individuals toward the social group [49]. Individuals with high social homogeneity tend to differentiate their social group from others and possess a positive ego. Social homogeneity is linked to high individual goals and the building of an ego for people with low self-esteem. Based on social identity theory, Schau and Gilly [50] suggested that in an online community, social identity is not a separate concept from that applied in offline environments. An online community provides an anonymous and flexible environment for relationships compared to an offline community, offering new opportunities to develop and express one's social identity. Social presence is described as "the degree of salience of the other person in the interaction and the consequent salience of the interpersonal relationships" [51] (p. 65). Social presence can be operationalized as the extent of awareness by other users in a social network.

\subsection{Service Usefulness as Service Factor for Adopting Mobile Social Apps}

Perceived customer value or the service quality of a specific SNS is the extent to which users perceive and realize consuming goals by participating in the SNS [52]. Perceived values include usefulness and playfulness, while perceived sacrifice encompasses technical effort, costs, and time [53]. Service quality indicates the extent to which users positively evaluate the services provided by the service provider through the website. Service quality refers to how users experience satisfactory, efficient, and reliable services. Service by mobile social apps which is not satisfactory results in a discontinuance of the use of the service. As dimensions or measures of service quality, for instance, Heim and Field [54] suggested four dimensions regarding the creation of e-service quality. Benilan et al. [55] indicated measures that extensively encompass service quality assessments in SaaS (software as a service). These include measures which permit consumers to assess their satisfaction with the reliability and business process 
of the service, which helps them assess service support overall. Thus, this study uses service usefulness, as it encompasses the most important aspects of service quality.

\subsection{Relationship Quality and Attitude toward Mobile Social Apps}

Relationship quality is a viable area of research, especially considering new types of relationships between parties [56]. Thus, this study posits that relationship quality indicates a user's attitude toward the provision of service of mobile social apps. As relationship quality components, trust and satisfaction have been suggested [57] and have been found to be significantly related to continued system usage or re-use [58]. Trust represents the belief that the service provider can provide benevolent and honest service [59]. Trust is crucial in creating and facilitating exchange processes. Trust demonstrates an allowance of vulnerability based on a positive expected future behavior by another party and significantly influences the behavioral intention of users [33]. Mutual trust is importantly related to P2P website "stickiness" [60]. Satisfaction, described as a positive emotional state resulted from cognitive appraisals, and can affect an individual's coping response.

Trust and satisfaction are crucial determinants of website usage or success. For instance, there are significant effects of trust on e-government success [61]. Mutual trust exerts a crucial impact on customers' loyalty to a website [60]. Trust is likely to improve the opinions of users regarding the integrity and ability of service provides to ensure protection of their personal information, and trust may enhance continuance usage [62]. Previous studies have also indicated a relationship between satisfaction and continuance usage intention $[63,64]$. If users are satisfied with a web community, they tend to be strongly connected to those in the community [65]. User commitment over the long term is not possible with continued dissatisfaction. Thus, user satisfaction is likely to result in continuous SNS usage [66]. Chu \& Kim [67] used expectation-confirmation and rational behavior theory to show that satisfaction has an effect on the continuous intention of usage for SNS. Yoon \& Rolland [68] adopted a technology acceptance model and the information systems (IS) success model to explain the impact of satisfaction on the continuance usage intention of SNS.

\section{Research Model}

This study focuses on (1) individual motivations such as reputation and helping others based on social exchange theory, and (2) relational capital such as continuing strengthened relationships, homogeneous groups and social identity, as these fit the wide base of users for which structural links cannot easily be captured. In addition to knowledge, the contribution content is diverse, such as chatting with friends, gaining information, and developing opinions. Our study intends to expand utilitarian or hedonic motivations for mobile social apps which focus on perceived value based on information and service quality, entertainment by showing another aspect of motivation based on social exchange theory [4], or social influence by encompassing additional variables related to individuation motivations toward participating in a social community.

Recently, studies of SNS have begun to focus on social capital formation in SNS [69]. Social capital is important for the organizational sharing and creation of knowledge [70]. When organizations offer an institutional condition amenable to the creation of social capital, organizations are better prepared for creating knowledge. A specific environment for exchanges and combinations of knowledge is established when (1) users are encouraged to participate in these exchanges, (2) structural connections or links exist between users (structural capital), (3) users possess the cognitive ability to capture and utilize knowledge (cognitive capital), and (4) users' relationships represent positive and strong traits (relational capital).

Relational capital reflects the affective nature of users' relationships. Relational capital is established when members strongly possess a social identification [71], understand and adhere to its cooperative norms [72], have trust in others in a group [38], and recognize the perception of obligatory participation in a group [43]. The relational aspect of social capital facilitates interactions between individuals within the structure, providing benefits to users and their community [43]. Simply because everyone belongs 
to a group and possesses an orientation toward a collective goal, they are encouraged to support other users [73]. Users interact with others in organizational networks due to a sense of moral duty to compensate for the help from others [74].

Relational capital is based on a commitment to a group such as an online network of practice [75] when a sense of responsibility to support others arises from the homogeneity of the group, social identity, or social presence. In an organizational online network, the contribution of valuable comments is encouraged by a sense of obligatory duty toward the group [76]. Social identification and reciprocity from participation, which are facets of relational capital, play a positive role in enhancing quality and quantity of knowledge sharing in an online community [11]. Based on studies on relational capital and its effect on online networks (e.g., $[11,74,75]$ ), our study suggests four social-capital-related variables for relationship quality: maintaining relational enhancement, social homogeneity, social identity, social presence.

\subsection{Individual Motivations}

This study suggests that individual motivations (promotional motivation, altruism, innovativeness, conformity) affect trust, satisfaction among mobile social app users, and attitudes toward mobile social app use based on social exchange theory for individual motivations (Figure 1).

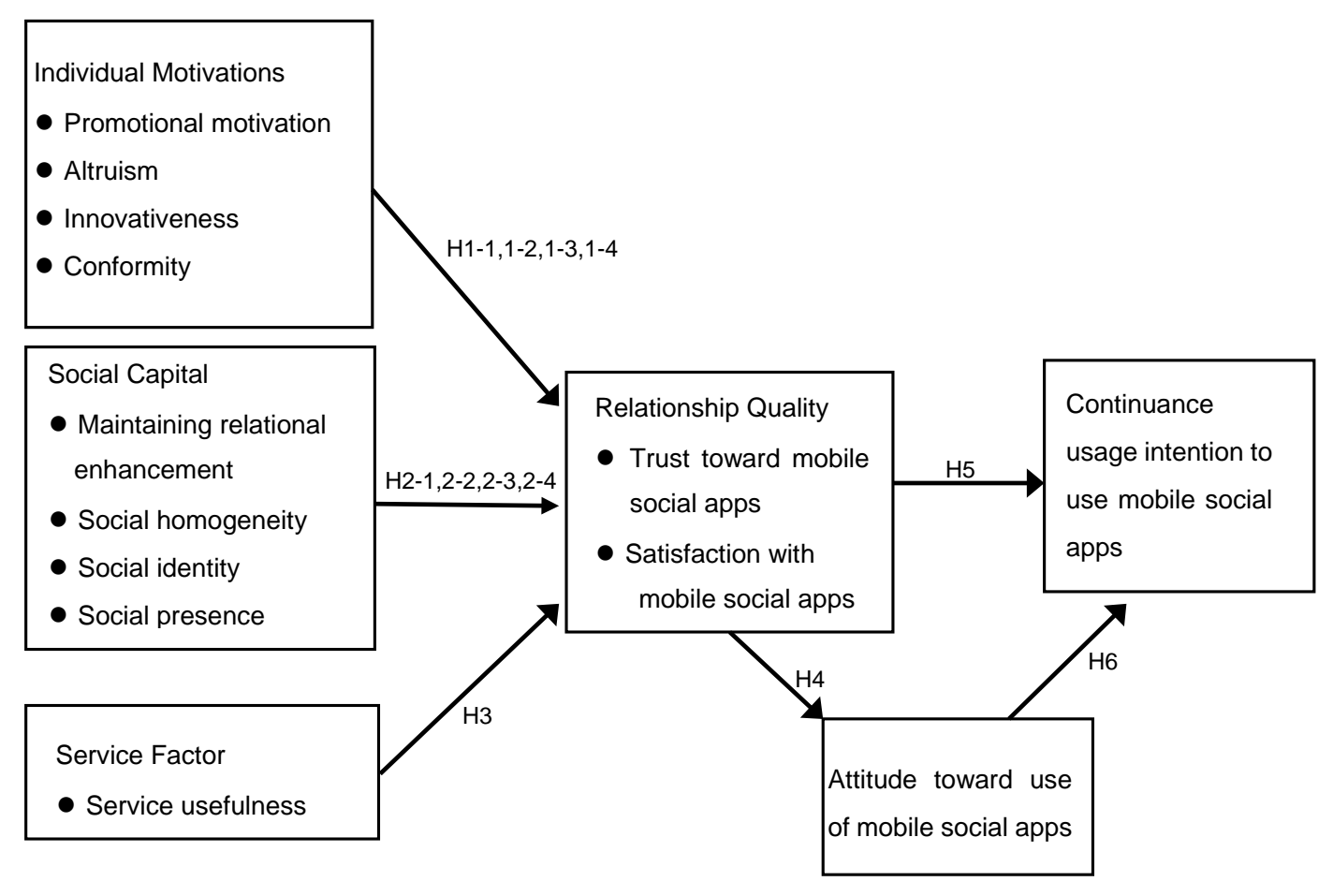

Figure 1. Research model.

The promotional motivation of mobile social apps represents the extent to which users intend to build a reputation with others and to be recognized or elevated by others. Social exchange theory [4] asserts that users participate in interactions because they expect that doing do will somehow produce rewards such as respect, status, and approval. As reputation comprises a crucial asset that a user can utilize to accomplish and retain status within a group [77], promotional motivation is important for mobile social app visitors to be willing to post their stories and opinions because they want to be recognized by others by their activities in mobile social apps. Creating a reputation is a strong facilitator for active commitment to online social networks, which is in line with social exchange theory [75]. The opportunity to enhance one's reputation offers a significant reason to provide useful comments to others in an online network [78]. If users enhance their activities, their posting behavior 
would attract others to interact. Then, the writer obtains the opportunity to provide useful comments to others, and those posted comments can enhance the reputation of the writer, which improves the writer's trust in and satisfaction with the mobile social app.

Hypothesis 1-1 (H1-1). The promotional motivation of mobile social app users positively affects relationship quality.

Altruism of SNS users is positive related to trust, satisfaction, and online group purchases [79]. Decentralization and storytelling based on altruism can support participatory practices [80]. The motivation to share knowledge can be based on enjoyment gained by helping others [81]. In the context of reciprocal altruism, users may be more encouraged to be influenced by other users who are altruistic [82]. Individuals are encouraged to provide knowledge to other users when they like helping other users [75]. Users can donate knowledge in an online network of practice as they consider helping others as challenging and interesting and perceive it as good to support other users [83]. Thus, users who commit to participate in social networks show altruism, and their posting behavior can provide the opportunity to create helpful comments for others; the posted comments can help users recognize that they are doing some good for others, which improves users' trust or satisfaction with mobile social apps. Thus, altruism may be posited to influence relationship quality.

Hypothesis 1-2 (H1-2). Altruism of mobile social app users positively affects relationship quality.

Innovativeness is described as the intention to attempt to use new technologies by individuals [84] and the degree of acceptance of new technologies earlier than others in the same social group after reviewing acceptance factors [85]. Innovative users are likely to accept new technologies and adapt themselves to changes stemming from technology adoption [86]. Thus, innovative users are likely to be generous to and have a favorable attitude toward new technology, and they enhance their participation activities. Then, these users intend to pursue the opportunity to offer and follow up useful comments through mobile social apps, which helps them perceive greater levels of trust and satisfaction, characterizing an ongoing social relationship.

Hypothesis 1-3 (H1-3). Innovativeness of mobile social app users positively affects relationship quality.

Conformity refers to the following of group activities despite differences between the group and individual values and beliefs [87]. Social conformity moderates the relationship between relationship quality and online buyers' intentions to participate in reputation systems related to C2C shopping [88]. Korea has a strong tendency toward conformity to group norms and values, which may strengthen the role of conformity with regard to trust and satisfaction, which characterize continuous social relationships in mobile social apps. If users are inclined to follow group activities and enhance their conforming social activities, their posting behavior would bring a sense of belonging and accomplishment as they obtain the opportunity to join community activities, which improves their trust or satisfaction with mobile social apps. Thus, conformity among mobile social app users has a positive influence on relationship quality.

Hypothesis 1-4 (H1-4). Conformity among mobile social app users positively affects relationship quality.

\subsection{Social Capital}

Our study posits that social capital is related to relationship quality, as social capital has an influence on trust from a sociological perspective [89]. Owing to the social and collaborative nature of mobile social apps, relational capital plays a significant role in encouraging users to continue using mobile social apps. In social virtual world services, relational capital facilitates affective commitment [90]. First, maintaining relational enhancement is to strengthen human relations with others in mobile social 
apps, differing from promotional motivation in that the latter refers to the motivation to spread a personal reputation and is not merely based on social relationships (e.g., bulletin boards, personal news or advertisement). Social communication is crucial to enjoyment and continuous relationship building in a SNS [91]. One's personal identification, which is a part of relational social capital, is established over the phases of a mentoring relationship and can affect the quality of the relationship over time [92]; in mentoring relations, relational quality includes personal learning and growth, inspiration, affirmation of self, shared influence and mutual respect, relational trust, and commitment [93]. Social bonds based on the expression of ideas and opinions can help build social bonds among mobile social app members and can facilitate the formation of trust among them. If users tend to maintain relational enhancement, their posting behavior would bring a sense of accomplishment, as they obtain the opportunity to enhance their social relationships through mobile social apps, which contributes to their trust or satisfaction with mobile social apps. Thus, maintaining relational enhancement affects trust and satisfaction, highlighting the characteristics of interpersonal relationships among users.

Hypothesis 2-1 (H2-1). Maintaining the relational enhancement of mobile social app users positively affects relationship quality.

This study suggests social homogeneity as the extent of the homogeneous nature of a group to which the user belongs. This differs from the conformity of mobile social app users, which is related to the motivation to adhere to social influences or norms. Support for communication is an important variable linked to social collaboration where the social composition of users is homogeneous [94]. Social factors, including the tendency to engage in social comparisons and follow subjective norms, have an impact on intention to use a specific service in a virtual community [95]. Online community users search for SNSs in which they perceive less cognitive dissonance and greater social homogeneity [96]. If users are inclined to belong to a homogeneous group, their posting behavior would bring a sense of membership in a homogeneous group by participating in its community activities, improving users' trust or satisfaction with mobile social apps. Thus, if users belong to a homogenous group, they tend to have trust and satisfaction and perceive the relationship quality of mobile social apps.

Hypothesis 2-2 (H2-2). Social homogeneity among mobile social app users positively affects relationship quality.

Social identity represents the emotional value which members assign to the sense of belonging to a SNS as a member [49]. Social identity represents the sense of belonging to an online community where users are motivated to enter into social interactions with other users. Students with lower self-esteem are likely to form heterogeneous and large networks that comprise media that can connect social capital [97]. This can be explained by the greater desire for social identity by students with low self-esteem. Social identity is posited to affect a user's adoption of a SNS [82]. Many online communities provide a cyberspace where social identity is built and valued. For instance, identification with an online brand community is affected by a consumer's identification with the brand [98]. Knowledge sharing and communication are possible using various relationships provided through mobile social apps, and as the expressions of ideas and opinions by people are becoming more recognized by others, they are motivated to participate in building a social identity in a community [75]. People intend to form personal identities by expressing themselves to accomplish personal goals through user-created content and the creation of personal sites [99]. SNS use may be considered as an activity influenced by social factors, and social identity positively affects customer activity within an online community [95]. As social identity in a SNS positively affects perceived encouragement, perceived usefulness, and perceived ease of use [82], social identity can exert a similar influence on relationship quality. If users have social identity when following group activities and this enhances their social activities, their posting behavior would enhance their social identity by bringing a sense of belonging and accomplishment, which improves users' trust or satisfaction with mobile social apps. 
Hypothesis 2-3 (H2-3). Social identity of mobile social app users positively affects relationship quality.

Social presence represents the extent to which a medium shows the perceived presence of users interacting through communication [51]. This is also represented as telepresence according to the network navigation model of Hoffman and Novak [100]. SNSs provide various services for cyber social activities which appear real, akin to experiences of social presence. The extent of perceived social presence in cyberspace is important for building trust, as social presence in B2C online services influences e-loyalty [101]. If a user perceives telepresence in a SNS, he/she is likely to obtain encouragement from other users [82]. Greater levels of perceived social presence exert an impact on the perceived enjoyment, trust, and usefulness of shopping mall sites, resulting in more favorable attitudes by consumers [102]. Awareness of social presence has been found to be important for enhancing and maintaining social connections [37] and relationship quality, which characterizes ongoing social relationships. If users are likely to pursue social presence and enhance their social activities, their posting behavior would create a sense of belonging and accomplishment, as they have the opportunity to enhance their social presence, which improves their trust or satisfaction with mobile social apps. Thus, social presence can have a positive effect on relationship quality in the context of mobile social apps.

Hypothesis 2-4 (H2-4). Social presence of mobile social app users positively affects relationship quality.

Service usefulness as a type of service quality intends to ensure that individuals experience satisfactory, efficient, and reliable service. In cases in which mobile social app service cannot be provided as expected, the result is a negative experience with the mobile social app and a possible discontinuance of use. Useful service permits users to solve their problems and establish relationship quality through B2C e-commerce [103]. Useful services can help users obtain the complete set of benefits satisfactorily, matching their expectations. If users experience useful services, they enhance their social activities to pursue their social goals more strongly with other users, improving their trust or satisfaction with mobile social apps. Thus, service usefulness has a positive impact on relationship quality.

Hypothesis 3 (H3). The service usefulness of mobile social apps positively affects relationship quality.

The literature on online communities suggests that satisfaction leads to greater participation in the community [65]. A long-term commitment may not be possible with persistent dissatisfaction. Thus, user satisfaction can increase continuous SNS usage [66]. Trust in an online community has been suggested as crucially related to knowledge sharing [104,105]. Teo et al. [61] discovered the impact of trust on e-government success. Mutual trust greatly influences C2C website "stickiness," as mentioned earlier [60]. If users no longer trust a SNS, they will not share information and will revoke their membership in the SNS, indicating that the trust of SNS users is crucial to the continuous usage of the SNS [106].

The impact of satisfaction on continuance usage intention has been widely investigated [64,107]. Previous studies posited that relationship quality exerts a positive effect on a user's intention to use an online service continually [108]. Satisfaction with mobile commerce is strongly related to the continuous usage intention of users [109]. Thus, relationship quality encompassing trust and satisfaction has a positive impact on attitudes toward the use of mobile social apps and continuance usage intention.

Lastly, a positive attitude toward the use of mobile social apps has a positive impact on the continuance usage intention of mobile social apps, as SNSs are a type of online technology, and the extent of acceptance may be similarly examined by a technology acceptance model [110].

Hypothesis 4 (H4). Relationship quality affects attitude toward use of mobile social apps. 
Hypothesis $\mathbf{5}$ (H5). Relationship quality affects the continuance usage intention of mobile social apps.

Hypothesis 6 (H6). A positive attitude toward the use of mobile social apps positively affects the continuance usage intention of mobile social apps.

\section{Methods}

\subsection{Sampling}

A survey questionnaire was revised based on proofreading by ten potential respondents and four IS professors. The word structures of the questions were improved in order to enable straightforward responses. The measurement items for each variable are presented in Table 1.

Data collection was done using an online survey site composed by one of the authors using a Google service based on a structured questionnaire. The target sample was initially chosen randomly from a list of undergraduate and graduate students registered at the researchers' schools, and requests containing the URL address of our online survey site were emailed so that potential respondents would complete the survey. The target sample of students was chosen because they are dedicated users of mobile social apps and are considered to answer surveys reliably. Secondly, the users who visiting the online survey site were asked whether they have routine experiences with mobile social apps as a condition presented on the first page of the online survey presented to users before they can continue with the survey. Respondents' identities were confirmed by their e-mail addresses in an effort to detect repetitive replies. We suggested examples of mobile social apps, including Facebook, Twitter, and Google+, and allowed the respondents to provide answers based on the mobile social apps which they most actively use. 
Table 1. The measurement items for each variable.

\begin{tabular}{|c|c|c|c|}
\hline Research Variables & & Items & Sources \\
\hline \multirow{4}{*}{ Promotional motivation } & REP1 & I like to have a reputation from others. & \multirow{4}{*}{ [75] } \\
\hline & REP2 & I like to be recognized by others. & \\
\hline & REP3 & I like to be elevated by others. & \\
\hline & REP4 & I like to become popular by others. & \\
\hline \multirow{4}{*}{ Altruism } & ALT1 & I console others in trouble. & \multirow{4}{*}[75,81]{} \\
\hline & ALT2 & I am good at answering others' questions. & \\
\hline & ALT3 & I am good at helping others who need help. & \\
\hline & ALT4 & I am good at providing favors to others. & \\
\hline \multirow{3}{*}{ Innovativeness } & INN1 & I am favorable to new information technology more than others. & \multirow{3}{*}[84,85,111]{} \\
\hline & INN2 & I tend to try to use new technology more than others. & \\
\hline & INN3 & I am familiar with new technology more than others. & \\
\hline \multirow{4}{*}{ Conformity } & CON1 & I tend to be somewhat sensitive to what others think about me. & \multirow{4}{*}{ [112-114] } \\
\hline & CON2 & I tend to be following others' opinions. & \\
\hline & CON3 & I like to know what others think about me. & \\
\hline & CON4 & $\begin{array}{l}\text { I take a look at others to have a hint in determining next actions in certain contexts when I am } \\
\text { unsure about actions. }\end{array}$ & \\
\hline \multirow{4}{*}{$\begin{array}{l}\text { Maintaining relational } \\
\text { enhancement }\end{array}$} & RLT1 & I feel strong bonds with others through mobile social apps. & \multirow{4}{*}{ [115-117] } \\
\hline & RLT2 & I maintain close relationship with others around me through mobile social apps. & \\
\hline & RLT3 & I make friends who become closer through mobile social apps. & \\
\hline & RLT4 & Through mobile social apps, I become closer to people who I already know. & \\
\hline \multirow{3}{*}{ Social homogeneity } & HOM1 & I think in a similar way with friends in mobile social apps. & \multirow{3}{*}[67,118,119]{} \\
\hline & HOM2 & I am acting in a similar way with friends in mobile social apps. & \\
\hline & HOM3 & My hobby and habits are similar to friends in mobile social apps. & \\
\hline
\end{tabular}


Table 1. Cont.

\begin{tabular}{|c|c|c|c|}
\hline Research Variables & & Items & Sources \\
\hline \multirow{3}{*}{ Social identity } & IDE1 & My position in mobile social apps which I am using is very important. & \multirow{3}{*}{ [82] } \\
\hline & IDE2 & I like to post letters or pictures in mobile social apps which I am using. & \\
\hline & IDE3 & My activities in mobile social apps are important parts of my life. & \\
\hline \multirow{4}{*}{ Social presence } & PRE1 & Mobile social apps provide experience of reality from location based service of mobile social apps. & \multirow{4}{*}[102,120,121]{} \\
\hline & PRE2 & Mobile social apps provides a realistic group meeting in group function. & \\
\hline & PRE3 & Mobile social apps provides experience of reality in invitation function. & \\
\hline & PRE4 & Mobile social apps enables realistic conversation from chatting function. & \\
\hline \multirow{4}{*}{ Service usefulness } & USE1 & Mobile social apps is useful in the service of finding friends. & \multirow{4}{*}[110,122]{} \\
\hline & USE2 & Mobile social apps is useful in messaging function service. & \\
\hline & USE3 & Mobile social apps is useful in group function service. & \\
\hline & USE4 & Mobile social apps is useful in invitation function service. & \\
\hline \multirow{5}{*}{ Trust toward mobile social apps } & TRU1 & The information from mobile social apps is reliable. & \multirow{5}{*}[106,107,123,124]{} \\
\hline & TRU2 & Mobile social apps which I am using has a high reputation. & \\
\hline & TRU3 & Mobile social apps which I am using provides a quality service. & \\
\hline & TRU4 & Mobile social apps which I am using is trustable. & \\
\hline & TRU5 & I have overall trust in information and service from mobile social apps. & \\
\hline \multirow{4}{*}{$\begin{array}{l}\text { Satisfaction with } \\
\text { mobile social apps }\end{array}$} & SAT1 & I am overall satisfied with mobile social apps use. & \multirow{4}{*}{ [125-127] } \\
\hline & SAT2 & I am satisfied with information provided from mobile social apps. & \\
\hline & SAT3 & I am satisfied with service provided from mobile social apps. & \\
\hline & SAT4 & Mobile social apps satisfies my expectation. & \\
\hline
\end{tabular}


Table 1. Cont

\begin{tabular}{|c|c|c|c|}
\hline Research Variables & & Items & Sources \\
\hline \multirow{6}{*}{$\begin{array}{l}\text { Attitude toward use of mobile } \\
\text { social apps }\end{array}$} & ATT1 & I feel OK with mobile social apps which I am using. & \multirow{6}{*}[128,129]{} \\
\hline & ATT2 & I am positive to mobile social apps which I am using. & \\
\hline & ATT3 & I feel favorable to mobile social apps which I am using. & \\
\hline & ATT4 & I like using mobile social apps which I am using. & \\
\hline & ATT5 & Mobile social apps is familiar to me. & \\
\hline & ATT6 & Mobile social apps is helpful to me. & \\
\hline \multirow{7}{*}{$\begin{array}{l}\text { Continuance usage intention to } \\
\text { use mobile social apps }\end{array}$} & CIN1 & I continue to use mobile social apps at the same pace with current use. & \multirow{7}{*}{ [130-132] } \\
\hline & CIN2 & I will continuously use mobile social apps without interruption. & \\
\hline & CIN3 & I have an intent to increase usage frequency of mobile social apps in the future. & \\
\hline & CIN4 & I will continuously use mobile social apps to share information with my acquaintances. & \\
\hline & CIN5 & I will use mobile social apps more than the other alternative medium. & \\
\hline & CIN6 & I have an intent to diverse mobile social apps if possible. & \\
\hline & CIN7 & I think that it is meaningful to continuously use mobile social apps in the future. & \\
\hline
\end{tabular}




\subsection{Data Collection}

In this study, 335 responses were received and 320 were finally included in the final sample after excluding 15 which were incompletely or unfaithfully answered. We determined the responses to include by examining the proportion of missing values in them, using the judgment of the researchers to distinguish random responses from valid ones (overly repetitive values for all items). Descriptive distributions of sample are given in Table 2 . The respondents were mostly male (58.8\%), in their twenties $(84.4 \%)$, and fulltime college students $(70.9 \%)$, as they are normally the most active users of mobile social apps. They use mobile social apps between $30 \mathrm{~min}$ and two hours per day $(55.9 \%)$ and have used them for more than two years $(71.6 \%)$.

Table 2. Descriptive characteristics of sample.

\begin{tabular}{|c|c|c|c|}
\hline & & Frequency & Percentage $(\%)$ \\
\hline \multirow{2}{*}{ Gender } & Female & 132 & 41.25 \\
\hline & Male & 188 & 58.75 \\
\hline \multirow{4}{*}{ Age } & $20 \mathrm{~s}$ & 270 & 84.38 \\
\hline & $30 \mathrm{~s}$ & 23 & 7.19 \\
\hline & $40 \mathrm{~s}$ & 22 & 6.87 \\
\hline & Older than 40 & 5 & 1.56 \\
\hline \multirow{4}{*}{ Education } & Middle school graduates & 11 & 3.44 \\
\hline & College student & 227 & 70.93 \\
\hline & College graduates & 72 & 22.50 \\
\hline & Having master degree or doctoral degree & 10 & 3.13 \\
\hline \multirow{8}{*}{ Job } & Student & 233 & 72.81 \\
\hline & Office employee & 19 & 5.94 \\
\hline & Specialized work & 35 & 10.94 \\
\hline & Sales/service & 9 & 2.81 \\
\hline & Technical/production & 10 & 3.12 \\
\hline & House wife & 7 & 2.19 \\
\hline & Self employed & 3 & 0.94 \\
\hline & Others & 4 & 1.25 \\
\hline \multirow{4}{*}{$\begin{array}{l}\text { Mobile social apps } \\
\text { usage time per day }\end{array}$} & Less than $30 \mathrm{~min}$ & 53 & 16.56 \\
\hline & 30 min $\sim$ one hour & 90 & 28.13 \\
\hline & One hour two hours & 89 & 27.81 \\
\hline & More than two hours & 88 & 27.50 \\
\hline \multirow{4}{*}{$\begin{array}{l}\text { Current mobile social } \\
\text { apps usage duration }\end{array}$} & Less than six months & 12 & 3.75 \\
\hline & Six months one year & 20 & 6.25 \\
\hline & One year two years & 59 & 18.44 \\
\hline & More than two years & 229 & 71.56 \\
\hline
\end{tabular}

\section{Results}

\subsection{Reliability and Validity of Measures}

As a test of convergence and discriminant validity, a principal component factor assessment with Varimax notation was conducted (Tables 3 and 4), the results of which explain 67.3 and 63.9 percent of the covariance among the independent and dependent variables. Factor loadings exceed the minimum factor loading of 0.5 as suggested by Hair et al. [133]. Our results reveal that all items were loaded on the same variable, as initially devised. The Cronbach alpha values of the research variables exhibit sufficient reliability because they exceed Nunnally's [134] reliability guidelines of 0.7 . Thus, the exploratory factor analysis and Cronbach alpha results validate the reliability and validity of the variables. 
Table 3. Factor analysis of independent variables.

\begin{tabular}{|c|c|c|c|c|c|c|c|c|c|c|c|}
\hline \multirow{2}{*}{ Variables } & \multirow{2}{*}{ Items } & \multicolumn{9}{|c|}{ Factor Loadings } & \multirow{2}{*}{ Communality } \\
\hline & & 1 & 2 & 3 & 4 & 5 & 6 & 7 & 8 & 9 & \\
\hline \multirow{4}{*}{ Promotional motivation } & REP1 & 0.721 & 0.198 & 0.127 & -0.017 & -0.172 & 0.039 & 0.114 & -0.018 & 0.137 & 0.639 \\
\hline & REP2 & 0.808 & 0.149 & -0.056 & 0.166 & 0.139 & 0.019 & -0.02 & 0.082 & 0.059 & 0.737 \\
\hline & REP3 & 0.816 & 0.097 & 0.098 & 0.21 & 0.004 & 0.083 & 0.182 & 0.151 & -0.019 & 0.791 \\
\hline & REP4 & 0.798 & 0.064 & -0.001 & 0.209 & 0.059 & 0.111 & 0.148 & 0.062 & 0.113 & 0.739 \\
\hline \multirow{4}{*}{ Altruism } & ALT1 & 0.18 & 0.665 & -0.058 & 0.132 & 0.161 & 0.112 & -0.178 & -0.014 & 0.086 & 0.573 \\
\hline & ALT2 & 0.226 & 0.665 & 0.071 & -0.053 & 0.19 & -0.016 & 0.07 & 0.071 & -0.025 & 0.548 \\
\hline & ALT3 & 0.038 & 0.838 & -0.006 & 0.021 & 0.089 & 0.013 & 0.044 & 0.091 & 0.049 & 0.725 \\
\hline & ALT4 & 0.056 & 0.753 & 0.02 & 0.08 & 0.027 & 0.039 & 0.119 & 0.172 & 0.157 & 0.647 \\
\hline \multirow{3}{*}{ Innovativeness } & INN1 & 0.011 & -0.011 & 0.823 & -0.004 & 0.014 & 0.023 & -0.045 & 0.087 & -0.022 & 0.688 \\
\hline & INN2 & 0.04 & 0.01 & 0.906 & 0.026 & 0.024 & 0.005 & 0.067 & 0.045 & -0.057 & 0.834 \\
\hline & INN3 & 0.069 & 0.028 & 0.878 & -0.014 & -0.018 & -0.022 & 0.053 & 0.006 & 0.045 & 0.783 \\
\hline \multirow{4}{*}{ Conformity } & CON1 & 0.26 & -0.001 & -0.026 & 0.686 & 0.147 & 0.067 & -0.021 & 0.103 & 0.127 & 0.593 \\
\hline & CON2 & -0.269 & -0.031 & -0.068 & 0.658 & -0.135 & 0.022 & 0.237 & 0.211 & -0.053 & 0.634 \\
\hline & CON3 & 0.304 & 0.131 & -0.056 & 0.768 & 0.003 & 0.031 & -0.016 & 0.034 & 0.045 & 0.707 \\
\hline & CON4 & 0.207 & 0.069 & 0.138 & 0.642 & 0.067 & 0.133 & -0.053 & -0.066 & 0.103 & 0.52 \\
\hline \multirow{4}{*}{$\begin{array}{l}\text { Maintaining relational } \\
\text { enhancement }\end{array}$} & RLT1 & 0.055 & 0.029 & 0.03 & 0.121 & 0.667 & 0.111 & 0.215 & 0.257 & 0.121 & 0.604 \\
\hline & RLT2 & -0.045 & 0.116 & -0.069 & -0.013 & 0.802 & -0.003 & 0.112 & 0.093 & 0.223 & 0.735 \\
\hline & RLT3 & 0.003 & 0.15 & 0.057 & -0.067 & 0.702 & 0.156 & 0.247 & 0.164 & 0.118 & 0.649 \\
\hline & RLT4 & 0.042 & 0.218 & 0.022 & 0.09 & 0.755 & 0.222 & 0.048 & 0.088 & 0.03 & 0.687 \\
\hline \multirow{3}{*}{ Social homogeneity } & HOM1 & 0.109 & 0.111 & 0.04 & 0.164 & 0.226 & 0.78 & 0.136 & 0.075 & 0.017 & 0.737 \\
\hline & HOM2 & 0.018 & 0.044 & -0.052 & 0.1 & 0.153 & 0.857 & 0.181 & 0.127 & 0.01 & 0.821 \\
\hline & HOM3 & 0.094 & -0.021 & 0.015 & -0.011 & 0.043 & 0.808 & 0.095 & 0.187 & 0.121 & 0.722 \\
\hline \multirow{3}{*}{ Social identity } & IDE1 & 0.129 & 0.002 & 0.064 & 0.067 & 0.097 & 0.078 & 0.696 & 0.162 & -0.106 & 0.563 \\
\hline & IDE2 & 0.115 & 0.051 & 0.014 & 0.003 & 0.18 & -0.007 & 0.774 & 0.134 & 0.157 & 0.691 \\
\hline & IDE3 & 0.104 & 0.028 & -0.007 & 0.094 & 0.14 & -0.004 & 0.77 & 0.092 & 0.264 & 0.711 \\
\hline
\end{tabular}


Table 3. Cont.

\begin{tabular}{|c|c|c|c|c|c|c|c|c|c|c|c|}
\hline \multirow{2}{*}{ Variables } & \multirow{2}{*}{ Items } & \multicolumn{9}{|c|}{ Factor Loadings } & \multirow{2}{*}{ Communality } \\
\hline & & 1 & 2 & 3 & 4 & 5 & 6 & 7 & 8 & 9 & \\
\hline \multirow{4}{*}{ Social presence } & PRE1 & 0.106 & 0.041 & -0.049 & 0.095 & 0.176 & 0.003 & 0.01 & 0.707 & 0.193 & 0.592 \\
\hline & PRE2 & 0.029 & 0.11 & 0.065 & 0.088 & 0.109 & 0.177 & 0.07 & 0.8 & 0.162 & 0.739 \\
\hline & PRE3 & 0.075 & 0.047 & 0.052 & -0.069 & 0.168 & 0.038 & 0.141 & 0.809 & 0.137 & 0.739 \\
\hline & PRE4 & 0.028 & 0.159 & 0.105 & 0.106 & 0.063 & 0.249 & 0.062 & 0.632 & 0.045 & 0.52 \\
\hline \multirow{4}{*}{ Service usefulness } & USE1 & 0.073 & 0.188 & -0.003 & 0.047 & 0.041 & 0.216 & -0.023 & 0.036 & 0.647 & 0.511 \\
\hline & USE2 & 0.068 & 0.013 & -0.043 & 0.133 & 0.229 & 0.066 & -0.051 & 0.057 & 0.818 & 0.756 \\
\hline & USE3 & 0.045 & 0.017 & -0.049 & 0.031 & 0.122 & -0.103 & 0.059 & 0.254 & 0.771 & 0.694 \\
\hline & USE4 & 0.115 & 0.066 & 0.078 & 0.025 & 0.07 & -0.011 & 0.191 & 0.356 & 0.611 & 0.566 \\
\hline \multicolumn{2}{|c|}{ Eigen Value } & 2.958 & 2.436 & 2.384 & 2.174 & 2.647 & 2.356 & 2.122 & 2.739 & 2.379 & \\
\hline \multicolumn{2}{|c|}{ Variance explained (\%) } & 8.964 & 7.382 & 7.225 & 6.588 & 8.02 & 7.139 & 6.429 & 8.3 & 7.21 & \\
\hline \multicolumn{2}{|c|}{ Cronbach's Alpha } & 0.856 & 0.759 & 0.85 & 0.685 & 0.816 & 0.839 & 0.74 & 0.802 & 0.756 & \\
\hline
\end{tabular}

Total cumulative variance explained $=67.26 \%, \mathrm{KMO}=0.795$, Bartlett test of sphericity $=3396.20, p=0.000$. 
Table 4. Factor analysis of dependent variables.

\begin{tabular}{|c|c|c|c|c|c|c|}
\hline \multirow{2}{*}{ Variables } & \multirow{2}{*}{ Items } & \multicolumn{4}{|c|}{ Factor Loadings } & \multirow{2}{*}{ Communality } \\
\hline & & 1 & 2 & 3 & 4 & \\
\hline \multirow{4}{*}{ Trust } & TRU1 & 0.726 & 0.158 & 0.006 & 0.153 & 0.575 \\
\hline & TRU3 & 0.669 & 0.113 & 0.234 & 0.193 & 0.553 \\
\hline & TRU4 & 0.812 & 0.161 & 0.053 & 0.118 & 0.703 \\
\hline & TRU5 & 0.822 & 0.155 & 0.168 & 0.102 & 0.738 \\
\hline \multirow{3}{*}{ Satisfaction } & SAT1 & 0.1 & 0.824 & 0.225 & 0.17 & 0.768 \\
\hline & SAT2 & 0.431 & 0.677 & 0.109 & 0.096 & 0.666 \\
\hline & SAT3 & 0.187 & 0.826 & 0.18 & 0.09 & 0.758 \\
\hline \multirow{4}{*}{$\begin{array}{l}\text { Attitude toward } \\
\text { use of mobile } \\
\text { social apps }\end{array}$} & ATT1 & 0.158 & 0.353 & 0.625 & 0.161 & 0.566 \\
\hline & ATT3 & 0.051 & 0.146 & 0.719 & 0.175 & 0.571 \\
\hline & ATT4 & 0.044 & 0.078 & 0.812 & 0.109 & 0.68 \\
\hline & ATT6 & 0.249 & 0.1 & 0.631 & 0.28 & 0.549 \\
\hline \multirow{5}{*}{$\begin{array}{l}\text { Continuance } \\
\text { usage intention } \\
\text { to use mobile } \\
\text { social apps }\end{array}$} & CIN1 & 0.056 & 0.109 & 0.054 & 0.794 & 0.648 \\
\hline & CIN2 & 0.044 & 0.07 & 0.102 & 0.812 & 0.677 \\
\hline & CIN4 & 0.157 & 0.186 & 0.228 & 0.739 & 0.658 \\
\hline & CIN5 & 0.243 & -0.017 & 0.21 & 0.664 & 0.544 \\
\hline & CIN7 & 0.273 & 0.145 & 0.305 & 0.615 & 0.567 \\
\hline \multicolumn{2}{|c|}{ Eigen Value } & 2.796 & 2.143 & 2.347 & 2.934 & \\
\hline \multicolumn{2}{|c|}{ Variance explained (\%) } & 17.472 & 13.393 & 14.67 & 18.341 & \\
\hline \multicolumn{2}{|c|}{ Cronbach's Alpha } & 0.81 & 0.794 & 0.797 & 0.829 & \\
\hline
\end{tabular}

In addition to an exploratory factor analysis, the confirmatory factor analysis conducted here shows high fitness of the model (Table 5). A second-order construct is used to measure relationship quality, as the study intends to measure relationship quality with the two inherent variables of trust and satisfaction. The confirmatory factor analytical procedure implemented in AMOS 22.0 was utilized to test the measurement model, which was tested with the structural model at the same time. The average variance extracted (AVE) for each variable exceeds 0.5 , indicating convergent validity of the variables. The internal composite reliability (ICR) shows sufficient reliability, as these values exceed 0.7. The square root of the AVE for each variable exceeds the correlations among the variables (Table 6), demonstrating that discriminant validity of the variables is established.

Table 5. Confirmatory factor analysis.

\begin{tabular}{cccccc}
\hline Variables & Items & $\begin{array}{c}\text { Factor } \\
\text { Loadings }\end{array}$ & $\boldsymbol{t}$-Value & $\begin{array}{c}\text { Average } \\
\text { Variance } \\
\text { Extracted }\end{array}$ & $\begin{array}{c}\text { Internal } \\
\text { Composite } \\
\text { Reliability }\end{array}$ \\
\hline \multirow{3}{*}{$\begin{array}{c}\text { Promotional } \\
\text { motivation }\end{array}$} & REP1 & 0.626 & 10.041 & & \\
& REP2 & 0.774 & 13.111 & 0.586 & 0.848 \\
& REP3 & 0.867 & 14.953 & & \\
& REP4 & 0.824 & - & & \\
Altruism & ALT1 & 0.606 & 7.855 & & \\
& ALT2 & 0.604 & 7.84 & 0.835 & \\
& ALT3 & 0.785 & 9.26 & & 0.865 \\
& ALT4 & 0.7 & - & & \\
\hline \multirow{2}{*}{ Innovativeness } & INN1 & 0.695 & 11.323 & & \\
& INN2 & 0.927 & 13.151 & 0.684 & \\
& INN3 & 0.81 & - & &
\end{tabular}


Table 5. Cont.

\begin{tabular}{|c|c|c|c|c|c|}
\hline Variables & Items & $\begin{array}{l}\text { Factor } \\
\text { Loadings }\end{array}$ & $t$-Value & $\begin{array}{l}\text { Average } \\
\text { Variance } \\
\text { Extracted }\end{array}$ & $\begin{array}{c}\text { Internal } \\
\text { Composite } \\
\text { Reliability }\end{array}$ \\
\hline \multirow{3}{*}{ Conformity } & CON1 & 0.654 & 7.24 & \multirow{3}{*}{0.594} & \multirow{3}{*}{0.76} \\
\hline & CON3 & 0.848 & 7.607 & & \\
\hline & CON4 & 0.568 & - & & \\
\hline \multirow{4}{*}{$\begin{array}{l}\text { Maintaining } \\
\text { relational } \\
\text { enhancement }\end{array}$} & RLT1 & 0.708 & 9.739 & \multirow{4}{*}{0.57} & \multirow{4}{*}{0.841} \\
\hline & RLT2 & 0.727 & 9.961 & & \\
\hline & RLT3 & 0.758 & 10.318 & & \\
\hline & RLT4 & 0.717 & - & & \\
\hline \multirow{3}{*}{ Social homogeneity } & HOM1 & 0.792 & 11.195 & \multirow{3}{*}{0.695} & \multirow{3}{*}{0.871} \\
\hline & HOM2 & 0.89 & 11.685 & & \\
\hline & HOM3 & 0.708 & - & & \\
\hline \multirow{2}{*}{ Social identity } & IDE2 & 0.724 & 9.282 & \multirow{2}{*}{0.58} & \multirow{2}{*}{0.733} \\
\hline & IDE3 & 0.855 & - & & \\
\hline \multirow{4}{*}{ Social presence } & PRE1 & 0.677 & 7.602 & \multirow{4}{*}{0.562} & \multirow{4}{*}{0.811} \\
\hline & PRE2 & 0.837 & 9.565 & & \\
\hline & PRE3 & 0.772 & 9.215 & & \\
\hline & PRE4 & 0.633 & - & & \\
\hline \multirow{4}{*}{ Service usefulness } & USE1 & 0.525 & 6.377 & \multirow{4}{*}{0.531} & \multirow{4}{*}{0.816} \\
\hline & USE2 & 0.81 & 9.065 & & \\
\hline & USE3 & 0.729 & 7.798 & & \\
\hline & USE4 & 0.71 & - & & \\
\hline \multirow{4}{*}{ Trust } & TRU1 & 0.665 & 10.339 & \multirow{4}{*}{0.614} & \multirow{4}{*}{0.863} \\
\hline & TRU3 & 0.631 & 9.728 & & \\
\hline & TRU4 & 0.77 & 12.186 & & \\
\hline & TRU5 & 0.824 & - & & \\
\hline \multirow{3}{*}{ Satisfaction } & SAT1 & 0.793 & 11.418 & \multirow{3}{*}{0.716} & \multirow{3}{*}{0.883} \\
\hline & SAT2 & 0.686 & 10.2 & & \\
\hline & SAT3 & 0.784 & - & & \\
\hline \multirow{4}{*}{$\begin{array}{l}\text { Attitude toward use } \\
\text { of mobile social apps }\end{array}$} & ATT1 & 0.696 & 9.115 & \multirow{4}{*}{0.522} & \\
\hline & ATT3 & 0.606 & 8.098 & & \\
\hline & ATT4 & 0.61 & 8.14 & & 0.845 \\
\hline & ATT6 & 0.693 & - & & \\
\hline & CIN1 & 0.602 & 8.411 & & \\
\hline Continuance usage & CIN2 & 0.637 & 8.905 & & \\
\hline intention to use & CIN4 & 0.801 & 10.936 & 0.589 & 0.865 \\
\hline mobile social apps & CIN5 & 0.671 & 9.397 & & \\
\hline & CIN7 & 0.727 & - & & \\
\hline $\begin{array}{c}\text { Second order } \\
\text { construct }\end{array}$ & & & & & \\
\hline & Trust & 0.831 & 23.37 & & \\
\hline Relationship quality & $\begin{array}{c}\text { User } \\
\text { Satisfaction }\end{array}$ & 0.865 & 16.72 & 0.727 & 0.813 \\
\hline
\end{tabular}


Table 6. Correlation analysis among variables.

\begin{tabular}{|c|c|c|c|c|c|c|c|c|c|c|c|c|c|}
\hline Variables & (1) & (2) & (3) & (4) & (5) & (6) & (7) & (8) & (9) & (10) & (11) & (12) & (13) \\
\hline Promotional motivation (1) & 0.766 & & & & & & & & & & & & \\
\hline Altruism (2) & 0.341 & 0.744 & & & & & & & & & & & \\
\hline Innovativeness (3) & 0.115 & 0.041 & 0.827 & & & & & & & & & & \\
\hline Conformity (4) & 0.558 & 0.268 & 0.019 & 0.721 & & & & & & & & & \\
\hline $\begin{array}{l}\text { Maintaining relational } \\
\text { enhancement (5) }\end{array}$ & 0.181 & 0.402 & 0.038 & 0.137 & 0.755 & & & & & & & & \\
\hline Social homogeneity (6) & 0.246 & 0.201 & 0.015 & 0.244 & 0.445 & 0.834 & & & & & & & \\
\hline Social identity (7) & 0.307 & 0.182 & 0.084 & 0.101 & 0.528 & 0.435 & 0.762 & & & & & & \\
\hline Social presence (8) & 0.246 & 0.319 & 0.126 & 0.205 & 0.472 & 0.366 & 0.325 & 0.721 & & & & & \\
\hline Service usefulness (9) & 0.278 & 0.251 & 0.001 & 0.264 & 0.434 & 0.19 & 0.271 & 0.49 & 0.729 & & & & \\
\hline Trust (10) & 0.18 & 0.231 & 0.1 & 0.089 & 0.438 & 0.485 & 0.577 & 0.323 & 0.238 & 0.783 & & & \\
\hline Satisfaction (11) & 0.325 & 0.237 & 0.087 & 0.24 & 0.451 & 0.341 & 0.462 & 0.326 & 0.417 & 0.494 & 0.846 & & \\
\hline $\begin{array}{l}\text { Attitude toward use of } \\
\text { mobile social apps (12) }\end{array}$ & 0.144 & 0.218 & -0.069 & 0.101 & 0.437 & 0.291 & 0.412 & 0.344 & 0.279 & 0.482 & 0.627 & 0.722 & \\
\hline $\begin{array}{l}\text { Continuance usage } \\
\text { intention to use mobile } \\
\text { social apps (13) }\end{array}$ & 0.2 & 0.249 & 0.035 & 0.246 & 0.481 & 0.387 & 0.49 & 0.356 & 0.283 & 0.482 & 0.465 & 0.648 & 0.751 \\
\hline
\end{tabular}

The diagonals represent square root of average variance extracted (AVE).

To investigate the common method variance (CMV), this study tested the measurement model with all items as indicators of a factor showing the method effect and re-estimated the model (Malhotra et al., 2006). The results presented poor fitness, showing that CMV was unlikely to be a serious problem.

\subsection{Test of Hypotheses}

The model fitness can be considered as good based on the fitness indices: $x^{2}=807.738, \mathrm{df}=674$, $x^{2} / \mathrm{df}=1.198, \mathrm{RMR}=0.042, \mathrm{GFI}=0.865, \mathrm{AGFI}=0.836, \mathrm{CFI}=0.966, \mathrm{NFI}=0.828, \mathrm{IFI}=0.967, \mathrm{TLI}=0.961$, and RMSEA $=0.029$. The fitness indices are within the ranges suggested by the guidelines stipulating a good model (RMR $\leq 0.05$, RMSEA $\leq 0.05$, GFI $\geq 0.8$, TLI $\geq 0.9)$ [135].

Figure 2 and Table 7 present the test results of the structural model. Among the paths from individual motivations to relationship quality, altruism and conformity fail to affect relationship quality. If users are active in promoting themselves and more favorable to new information technology than others, they tend to have trust and satisfaction, which affect their continuous use of mobile social apps. However, helping others or conforming to social norms is not directly related to trust and satisfaction with the current mobile social app service. Users who like helping others or following others do not always have trust and satisfaction with mobile social apps. Altruism and conformity, which are factors that depend upon others, are not sufficient reasons for trust and satisfaction with mobile social apps. Even when users are good at answering others' questions and tend to be somewhat sensitive to what others think about them, they may not have trust or be satisfied with mobile social apps.

Among social capital factors, maintaining relational enhancement, social homogeneity, and social identity are important determinants of relationship quality, while social presence has an insignificant effect on relationship quality. Even when users feel realistic bonds with others through mobile social apps and maintain a social presence with others around them through mobile social apps, they may not feel complete trust and satisfaction with mobile social apps. In order to improve trust and satisfaction, mobile social app services should be devised such that they maintain relational enhancement and enhance social homogeneity and social identity. When users think in a similar way with friends on mobile social apps and act in a similar way with these friends, they can feel trust and satisfaction with mobile social apps and continue their usage of these apps. Thus, maintaining relational enhancement, social homogeneity and identity are more important social capital factors than social presence. When users' positions on a mobile social app are very important and users like to post letters or pictures on these apps, they can feel trust and satisfaction with the apps. The insignificant effect of social presence on relationship quality indicates that while users do not perceive much experience of a 
social presence from location-based services, an invitation function, or a chatting function of a mobile social app, they can still feel trust and satisfaction with the mobile social app.

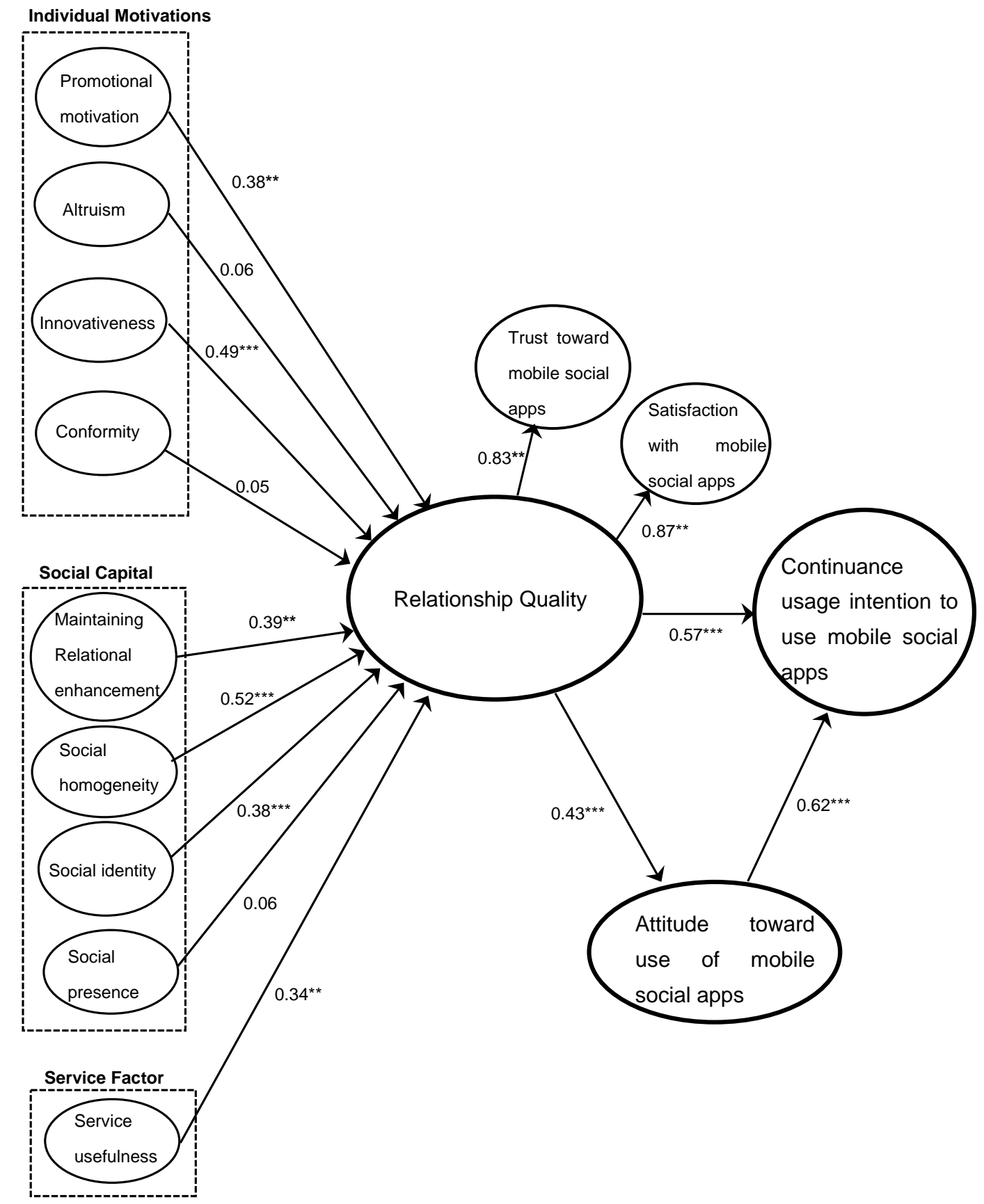

Figure 2. Test of structural model. ${ }^{* *}: p$-value $<0.01,{ }^{* * *}: p$-value $<0.001$.

Among the dependent variables, all paths are significant. This indicates that when users feel trust and satisfaction with mobile social apps, they are likely to continue using the mobile social apps. Relationship quality has a strong impact on continuance usage intention to adopt mobile social apps, indicating that when users perceive that mobile social apps are trustful or that they bring satisfaction, they will continue to use mobile social apps. 
Table 7. Results of hypothesis testing.

\begin{tabular}{|c|c|c|c|c|c|}
\hline Hypothesis & Path & Coefficient & $t$-Value & $p$-Value & Test Result \\
\hline H1-1 & $\begin{array}{l}\text { Promotional motivation } \longrightarrow \\
\text { Relationship quality }\end{array}$ & $0.375^{* *}$ & 3.073 & 0.006 & Accept \\
\hline $\mathrm{H} 1-2$ & Altruism $\longrightarrow$ Relationship quality & 0.059 & 1.247 & 0.154 & Reject \\
\hline H1-3 & $\begin{array}{l}\text { Innovativeness } \longrightarrow \\
\text { Relationship quality }\end{array}$ & $0.485^{* * *}$ & 3.761 & 0 & Accept \\
\hline H1-4 & Conformity $\longrightarrow$ Relationship quality & 0.047 & 0.862 & 0.269 & Reject \\
\hline $\mathrm{H} 2-1$ & $\begin{array}{l}\text { Maintaining relational enhancement } \\
\longrightarrow \text { Relationship quality }\end{array}$ & $0.392 * *$ & 2.675 & 0.003 & Accept \\
\hline $\mathrm{H} 2-2$ & $\begin{array}{l}\text { Social homogeneity } \longrightarrow \\
\text { Relationship quality }\end{array}$ & $0.516^{* * *}$ & 3.86 & 0 & Accept \\
\hline $\mathrm{H} 2-3$ & $\begin{array}{l}\text { Social identity } \longrightarrow \\
\text { Relationship quality }\end{array}$ & $0.379 * * *$ & 3.892 & 0 & Accept \\
\hline $\mathrm{H} 2-4$ & $\begin{array}{l}\text { Social presence } \longrightarrow \\
\text { Relationship quality }\end{array}$ & 0.058 & 1.48 & 0.371 & Reject \\
\hline H3 & $\begin{array}{l}\text { Service usefulness } \longrightarrow \\
\text { Relationship quality }\end{array}$ & $0.336^{* *}$ & 4.852 & 0.008 & Accept \\
\hline $\mathrm{H} 4$ & $\begin{array}{l}\text { Relationship quality } \longrightarrow \text { Attitude } \\
\text { toward mobile social apps use }\end{array}$ & $0.427^{* * *}$ & 3.395 & 0 & Accept \\
\hline H5 & $\begin{array}{l}\text { Relationship quality } \longrightarrow \text { Continuance } \\
\text { usage intention to use mobile } \\
\text { social apps }\end{array}$ & $0.568^{* * *}$ & 4.482 & 0 & Accept \\
\hline H6 & $\begin{array}{l}\text { Attitude toward mobile social apps } \\
\text { use } \longrightarrow \text { Continuance usage intention } \\
\text { to use mobile social apps }\end{array}$ & $0.623^{* * *}$ & 5.235 & 0 & Accept \\
\hline
\end{tabular}

\section{Discussions}

The significant effect of promotional motivation on relational quality supports its important connection to participation in an online network [75] and shows that users are likely to have trust and satisfaction when they prefer to be acknowledged by others or like to gain a reputation from others. Users obtain trust and satisfaction, intending to use mobile social apps continuously when they like to be elevated by others and like to become popular with others. Innovativeness has a significant effect on relationship quality, and this indicates that innovative users have trust and satisfaction with mobile social apps because they adapt themselves to the changes resulting from technology adoption and support the notion of Rogers [85], who holds that innovativeness is one of the key factors enabling users to use additional new technologies.

Further, altruism has an insignificant effect on relationship quality, indicating that when users are good at answering others' questions or helping others who need help, they are not always likely to have trust and satisfaction with mobile social apps. This shows the motivation to help other does not always lead to having trust and satisfaction. Conformity insignificantly affects relationship quality, showing that if users tend to be somewhat sensitive to what others think about them or tend to follow others' opinions, they may not always have trust or satisfaction with mobile social apps. Confirming to online community values or norms does not result in trust and satisfaction.

The influence of maintaining a relational enhancement on relationship quality is significant, a finding consistent with Zhou et al. [90] regarding the impact of relational capital on affective commitment in a social virtual world. This shows that when users feel strong bonds with others through mobile social apps or maintain close relationship with others through mobile social apps, they have more trust and satisfaction with mobile social apps. The effects of social homogeneity and social identity on relationship quality are strong, consistent with Song and Kim [95] regarding the effect of the tendency to build a social identity on the behavioral intention to use a specific online service. This indicates that if users perceive that they belong to a homogeneous group and consider their position in mobile social apps as an important part of life and like to post messages or pictures on mobile social apps, they are likely to have trust and satisfaction with mobile social apps. 
The impact of social presence on trust and satisfaction with mobile social apps is insignificant, showing that while mobile social apps may provide the experience of social presence from location-based services of mobile social apps and mobile social apps provide a realistic group meeting in a group function, users are not always likely to have trust and satisfaction with mobile social apps from the effect of social presence. The impact of service usefulness on relationship quality, however, is significant, supporting the work of Zhang et al. [103], which posits the importance of service usefulness and showing that if a SNS provides a useful service, such as a friend-finding service, a messaging function service, a group function service, and an invitation function service, users are likely to have trust and satisfaction with the mobile social app.

Relationship quality has a strong impact on attitude and continuance usage intention to use mobile social apps, a finding which supports $[60,64,104]$ regarding the impact of trust and satisfaction on usage intention. This indicates that trust and satisfaction are important factors for continuous use. The significant impact of attitude toward mobile social apps use on continuance usage intention to use mobile social apps confirms that TAM (technology acceptance model) remains effective with regard to explaining the use of mobile social apps.

\section{Conclusions and Implications}

Although theories of collective action and social capital can be useful when attempting to understand individuals' behaviors, studies that apply these theories of continuance usage intention are rare. Based on theories of collective action and social capital, the purpose of the present study is to investigate individual motivations and social capital, which affect relationship quality encompassing trust and satisfaction with mobile social apps, which in turn affect attitudes toward use and continuance usage intentions of mobile social apps.

The results indicate that as individual motivations, promotional motivation and innovativeness affect relationship quality. As social capital, maintaining relational enhancement, social homogeneity, and social identity along with service usefulness have a strong impact on relationship quality, which in turn influences attitude toward use and continuance usage intention. Our study indicates the importance of enhancing individual motivations and social capital for the continuance usage of mobile social apps. Based on a number of studies on the continuous usage of SNS, our study provides the factors comprised for affecting the sustainable use of mobile social apps which are creating much more business ramification than desktop applications as the dependence of business processes on smart devices becomes greater. Thus, sustainability issues can be considered in devising factors affecting the continuous usage (similar to sustainable use) of social apps.

\subsection{Implications for Researchers}

Our study offers several implications to researchers. First, the study provides an insightful extension of the literature on individual motivations as they pertain to mobile social apps, as studies of individual motivations are lacking in relation to mobile social apps. It is necessary to study another facet of motivation based on social exchange theory or social influence by considering specific variables related to individuation motivations to participating in a social community. The results here demonstrate the importance of promotional motivation and innovativeness in that users who like to promote themselves and innovative users have trust and satisfaction with mobile social apps use, indicating that these users have stronger motivations to be socially popular and have higher technological or service expectations toward mobile social apps, leading them also to have trust and satisfaction with the use of mobile social apps. The difference in our approach is that a second-order construct is utilized here to measure relationship quality. Previous studies scarcely investigated effects on relationship quality with a second-order construct encompassing trust and satisfaction.

Secondly, this study provides insight into the potential value of social capital to promote continuance usage intention. Social capital can also be reduced through under-use, and social media users are always seeking the next new factor [14] and can influence social media success [15]. Moreover, 
users with weak social capital are likely less utilize social media, as they have not realized the intended goal of social media to increase social capital $[16,17,19]$. As the pace and power of social media are having a significant impact worldwide on expanding networks [21], it is crucial to investigate the effects of social capital as built by social media on the continuous usage of social media in order to validate empirically the role of social capital by social media to attract participants. This study intends to bridge this gap in the literature by suggesting four social-capital-related variables: maintaining relational enhancement, social homogeneity, social identity, and social presence based on the theory of collective action and on social capital theory. This is in line with previous studies which posit that social capital produces an opportunity for actors to obtain information resources on a SNS and to share information and positive emotions, benefiting individuals and their organizations [2]. Our study also provides insights in relation to previous studies of online communities, electronic networks for practice, and social virtual world services $[22,74,75,90]$ by showing that theories of social capital can be utilized to investigate how social capital affects continuous usage intentions. Based on the literatures of social capital, in the context of mobile social apps, where user behavior may have effects on or be affected by other actors beyond knowledge contribution, this study applies theories of collective action and social capital by suggesting four variables related to social capital in an effort to understand the effects of social influence as experienced by individuals as members of social networks on their continuance usage intentions.

Thirdly, this study adopts relationship quality, encompassing trust in and satisfaction with mobile social apps, as a mediating variable of the impact of individual motivations and social capital on continuance usage intention. While there have been several studies of factors affecting trust and satisfaction $[24,25]$, studies on individual motivations and social capital on the relationship quality of mobile social apps are rare. This study examines how users' motivations and social behavior can have effects on trust or satisfaction when they interact with other actors. Thus, the study of individual motivations and social capital related to relationship quality provides implications for current researchers of mobile social apps.

The study has several limitations as well as areas of future research on mobile social apps. First, the sample lacks diversity in that it mostly consists of those aged 20-29 and who are college students. This may be an issue when attempting to generalize the results to the general public, who have diverse occupations and ages. Second, different effects of user motivations and social capital can be suggested according to different user groups in terms of gender, age, and occupation. Differences in trust, satisfaction, and attitudes toward mobile social apps according to different user groups can also inform future research issues. This will help to suggest promising marketing strategies to promote the continued use of mobile social apps to various user groups. Third, as the use of mobile social apps is rapidly increasing and more strongly relying on mobile platforms, research that suggests different factors affecting the transition to mobile social apps is necessary. Fourth, altruism by mobile social app users does not lead to user trust or satisfaction, indicating that users with altruism are mostly motivated to help others or interact with them out of goodwill, not necessarily resulting in their trust and satisfaction. Similarly, conformity fails to affect relationship quality, showing that factors such as altruism and conformity are intrinsic personal factors not affecting trust or satisfaction. Thus, as previous studies lack investigations of altruism or conformity, these can be promising variables when studying their effects on trust and satisfaction in the future. Fifth, the research model can be expanded by adding new variables related to sustainability, such as social participation, community engagement, and social engagement with sustainability in future studies.

\subsection{Implications for Practitioners}

As mobile social apps are faced with a significant decrease in active usage, the results of the study provide implications for practitioners in that individual motivations and social capital can be practically reflected in the design of mobile social apps. The significant effects of maintaining relational enhancement, social homogeneity, and social identity and the insignificant impact of social 
presence on relationship quality show that the design of mobile social apps should be directed toward enhancing more relationships based on homogeneous social group and social identity in these groups rather than focusing on service presence based on the realistic experience of two-way communication. Service usefulness significantly influences relationship quality, showing that mobile social app users generally recognize trust and are satisfied, and have positive attitudes toward mobile social apps when mobile social apps focus more on tools, widgets, and applications in order to improve service usefulness, mobile social apps are more likely to show increased continuance usage intention.

As promotional motivation and social identity are strongly related to trust and satisfaction with mobile social apps, mobile social app service providers should place more importance on protecting users' reputations, statuses, and popularity on their sites by employing security measures to reduce as much as possible postings with bad intentions to harm the reputations of other users with no reasonable basis. If ungrounded assaults on others' fame, reputations, or privacy are discovered in cyberspace, these postings should be deleted as soon as possible. The social identity of users, which represents their social status and trends of activity on the site, are crucial in the building of trust and satisfaction and facilitating the use of mobile social apps. By highlighting the number of followers, consenters, and impressed users, for example, mobile social apps managers should focus on emphasizing the social identity of users by encouraging them to express ideas and opinions which are diverse and represent the unique characteristics of users.

As increasing numbers of services of mobile social apps are becoming similar across different sites, it is now necessary to develop differentiated services to promote reputation and attract innovative users. For example, regarding the promotional motivation of users, services should highlight the number of followers or provide reposting for each post, which can serve as a reward to enhance promotional motivation. Mobile social app services should be more customized to support interactions among users using incentives such as coupons if they show promotional motivation. Regarding the innovativeness of users, services satisfying certain traits of users, such as a service based on the state-of-the-art design of the site, can be considered to encourage experience with current sophisticated social technologies and businesses.

The maintaining relational enhancement is related to relationship quality. Therefore, if mobile social apps enhance their security functions to protect the closeness of relationships, this will affect trust and satisfaction with mobile social apps and have an influence on continuance usage intentions. Thus, it is necessary to improve the security image of mobile social apps, ensuring the effect of relationships among users on trust and satisfaction with mobile social apps. The homogeneity and social identity of a social group may be helpful when attempting to understand trust and satisfaction with mobile social apps and are relevant factors for determining the intention to use mobile social apps. This shows that as the level of homogeneity and social identity recognized by the same group are increasing, mobile social app service providers can expect high trust and satisfaction levels from these users. Service providers should maintain high levels of security functions ensuring homogeneity and social identity of such groups to manage the trust and satisfaction of users. For social homogeneity and social identity, more customized small communities should be devised and encouraged in order to ensure continuance usage intentions.

If users feel trust and are satisfied with the current site, the current trust and satisfaction level can help to predict the possible future usage extent. Users can move to another site anytime as a communication channel which they discover that it fits their personal and social needs and find more attractive services at those sites. Mobile social app service providers should not be highly optimistic about trust and user satisfaction and should evaluate how much their users have trust and satisfaction with their mobile social apps, as well as actual intentions to engage in further use.

Author Contributions: Conceptualization, S.L.; methodology, S.L.; software, S.L. and B.G.K.; validation, S.L.; formal analysis, S.L.; investigation, S.L.; resources, B.G.K.; data curation, B.G.K.; writing-original draft preparations, writing-review and editing, S.L.; supervision, S.L.; funding acquisition, B.G.K. All authors have read and agreed to the published version of the manuscript. 
Funding: The research was funded by Namseoul University.

Conflicts of Interest: The authors declare no conflict of interest.

\section{References}

1. Statista, Number of Monthly Active Facebook Users Worldwide as of 2nd Quarter 2020 (In Millions). Available online: https:/www.statista.com/statistics/264810/number-of-monthly-active-facebook-usersworldwide/ (accessed on 13 September 2020).

2. Colbert, A.E.; Bono, J.E.; Purvanova, R.K. Flourishing via workplace relationships: Moving beyond instrumental support. Acad. Manag. J. 2016, 59, 1199-1223. [CrossRef]

3. CNBC PEAK SOCIAL? The Major Social Platforms are Showing a Significant Slowdown in Users. 2018. Available online: https://www.cnbc.com/2018/08/08/social-media-active-users-around-the-world.html (accessed on 1 September 2020).

4. Blau, P.M. Exchange and Power in Social Life; Wiley: New York, NY, USA, 1964.

5. Lee, S.; Kim, B.G. The impact of qualities of social network service on the continuance usage intention. Manag. Decis. 2017, 55, 701-729. [CrossRef]

6. Han, S.; Min, J.; Lee, H. Antecedents of social presence and gratification of social connection needs in SNS: A study of Twitter users and their mobile and non-mobile. Int. J. Inf. Manag. 2015, 35, 459-471. [CrossRef]

7. Huang, L.-Y.; Hsieh, Y.-J.; Wu, Y.-C.J. Gratifications and social network service usage: The mediating role of online experience. Inf. Manag. 2014, 51, 774-782. [CrossRef]

8. Investopedia, Social Capital. Available online: https://www.investopedia.com/terms/s/socialcapital.asp (accessed on 11 September 2020).

9. Neves, B.B.; Fonseca, J.R.S.; Amaro, F.; Pasqualotti, A. Social capital and Internet use in an age-comparative perspective with a focus on later life. PLOS ONE 2018, 13, e0192119.

10. Hyun, H.; Gunn, F.; Park, J. The influence of social capital through social media: A study of the creation of value in shopping behavior. Int. Rev. Retail. Consum. Res. 2019, 29, 160-177. [CrossRef]

11. Chang, H.H.; Chuang, S.-S. Social capital and individual motivations on knowledge sharing: Participant involvement as a moderator. Inf. Manag. 2011, 48, 9-18. [CrossRef]

12. Keenfolks, Why Social Capital Should be Central to Your Digital Transformation Strategy. Available online: https://thekeenfolks.com/keensights/social-capital/ (accessed on 11 September 2020).

13. Kwon, S.-W.; Asler, P.S. Social capital: Maturation of a field of research. Acad. Manag. Rev. 2014, 39, 412-422. [CrossRef]

14. Khoros, How Understanding Social Capital Will Boost Your Social Media Efforts. Available online: https: //khoros.com/blog/how-understanding-social-capital-will-boost-your-social-media-efforts (accessed on 11 September 2020).

15. Krishen, A.S.; Leenders, M.A.A.M.; Muthaly, S.; Ziółkowska, M.; LaTour, M.S. Social networking from a social capital perspective: A cross-cultural analysis. Eur. J. Mark. 2019, 53, 1234-1253. [CrossRef]

16. Bush, C.L. Online Social Capital: Social Networking Sites' Influence on Civic and Political Engagement. Master's Thesis, Sociology/Criminal Justice. Old Dominion University, Norfolk, VA, USA, 2018. Available online: https://digitalcommons.odu.edu/sociology_criminaljustice_etds/18 (accessed on 15 September 2020). [CrossRef]

17. Naseri, S. Online social network sites and social capital: A case of Facebook. Int. J. Appl. Sociol. 2017, 7, 13-19.

18. Sawyer, J.M.; Sallnow, L.; Kupeli, N.; Stone, P.; Sampson, E.L. Social networks, social capital and end-of-life care for people with dementia: A realist review. BMJ Open 2019, 9, e030703. [CrossRef] [PubMed]

19. Williams, J.R. The use of online social networking sites to nurture and cultivate bonding social capital: A systematic review of the literature from 1997 to 2018. New Media Soc. 2019, 21, 2710-2729. [CrossRef]

20. Management Study Guide, Impact of Social Networking Sites on Social Capital. Available online: https://www.managementstudyguide.com/social-networking-sites-and-social-capital.htm (accessed on 12 September 2020).

21. Premiere People-Part of the Cordant Group, Power of Social Media. Available online: http://www. premierepeople-ni.com/resources/power-of-social-media (accessed on 12 September 2020).

22. Faraj, S.; Kudaravalli, S.; Wasko, M. Leading collaboration in online communities. Mis Q. 2015, 39, $393-412$. [CrossRef] 
23. Kang, S.; Na, Y.K. The effect of the relationship characteristics and social capital of the sharing economy business on the social network, relationship competitive advantage, and continuance commitment. Sustainability 2018, 10, 2203. [CrossRef]

24. Chow, W.; Shi, S. Investigating customers' satisfaction with brand pages in social networking sites. J. Comput. Inf. Syst. 2015, 55, 48-58. [CrossRef]

25. Wang, X.; Li, Y. Users' satisfaction with social network sites: A self-determination perspective. J. Comput. Inf. Syst. 2015, 56, 48-54. [CrossRef]

26. Hossain, M.A.; Kim, M.; Jahan, N. Can “Liking” behavior lead to usage intention on Facebook? Uses and gratification theory perspective. Sustainability 2019, 11, 1166. [CrossRef]

27. Kim, S.H.; Bae, J.B.; Jeon, H.M. Continuous intention on accommodation apps: Integrated value-Based adoption and expectation-confirmation model analysis. Sustainability 2019, 11, 1578. [CrossRef]

28. Lee, S.W.; Sung, H.J.; Jeon, H.M. Determinants of continuous intention on food delivery apps: Extending UTAUT2 with information quality. Sustainability 2019, 11, 3141. [CrossRef]

29. Ruangkanjanases, A.; Hsu, S.-L.; Wu, Y.J.; Chen, S.-C.; Chang, J.-Y. What drives continuance Intention towards social media? Social influence and identity perspectives. Sustainability 2020, 12, 7081. [CrossRef]

30. Zhang, J.; Luximon, Y.; Song, Y. The role of consumers' perceived security, perceived control, interface design features, and conscientiousness in continuous use of mobile payment services. Sustainability 2019, 11, 6843. [CrossRef]

31. Zhou, T.; Li, H.X.; Liu, Y. The effect of flow experience on mobile SNS users' loyalty. Ind. Manag. Data Syst. 2010, 110, 930-946. [CrossRef]

32. Lin, K.-Y.; Lu, H.-P. Why people use social networking sites: An empirical study integrating network externalities and motivation theory. Comput. Hum. Behav. 2011, 27, 1152-1161. [CrossRef]

33. Lankton, N.K.; McKnight, D.H.; Thatcher, J.B. The moderating effects of privacy restrictiveness and experience on trusting beliefs and habit: An empirical test of intention to continue using a social networking website. IEEE Trans. Eng. Manag. 2012, 59, 654-665. [CrossRef]

34. McKnight, D.H.; Choudhury, V.; Kacmar, C. Developing and validating trust measures for e-commerce: An integrative typology. Inf. Syst. Res. 2002, 13, 334-359. [CrossRef]

35. Alarcon-del-Amo, M.-C.; Lorenzo-Romero, C.; Gomez-Borja, M.-Á.C. Classifying and profiling social networking site users: A latent segmentation approach. Cyberpsychol. Behav. Soc. Netw. 2011, 14, 547-553. [CrossRef]

36. Martínez-López, F.J.; Pla-García, C.; Gázquez-Abad, J.C.; Rodríguez-Ardura, I. Utilitarian motivations in online consumption: Dimensional structure and scales. Electron. Commer. Res. Appl. 2014, 13, 188-204. [CrossRef]

37. Lin, H.; Fan, W.; Chau, P. Determinants of users' continuance of social networking sites: A self-regulation perspective. Inf. Manag. 2014, 51, 595-603. [CrossRef]

38. Putnam, R. Tuning in, tuning out: The strange disappearance of social capital in America. Political Sci. Politics 1995, 28, 664-683. [CrossRef]

39. Wang, Y.L.; Meister, D.B.; Gray, P.H. Social influence and knowledge management systems use: Evidence from panel data. Mis Q. 2013, 37, 299-313. [CrossRef]

40. Ku, Y.-C.; Chen, R.; Zhang, H. Why do users continue using social networking sites? An exploratory study of members in the United States and Taiwan. Inf. Manag. 2013, 50, 571-581. [CrossRef]

41. Baker, R.K.; White, K.M. Predicting adolescents' use of social networking sites from an extended theory of planned behaviour perspective. Comput. Hum. Behav. 2010, 26, 1591-1597. [CrossRef]

42. Lin, N. Social Capital; Cambridge University Press: Cambridge, UK, 2001.

43. Coleman, J.S. Foundations of Social Theory; Belknap Press: Cambridge, MA, USA, 1990.

44. Madhavaram, S.; Hunt, S.D. Customizing business-to-business (B2B) professional services: The role of intellectual capital and internal social capital. J. Bus. Res. 2017, 74, 38-46. [CrossRef]

45. Pillai, K.G.; Hodgkinson, G.P.; Kalyanaram, G.; Nair, S.R. The negative effects of social capital in organizations: A review and extension. Int. J. Manag. Rev. 2017, 19, 97-124. [CrossRef]

46. Waters, E.; Sroufe, L. Social competence as a developmental construct. Dev. Rev. 1983, 3, 79-97. [CrossRef]

47. Carnabuci, G.; Diószegi, B. Social networks, cognitive style, and innovative performance: A contingency perspective. Acad. Manag. J. 2015, 58, 881-905. [CrossRef] 
48. Park, S.Y.; Cha, S.-B.; Lim, K.; Jung, S.-H. The relationship between university student learning outcomes and participation in social network services, social acceptance and attitude towards school life. Br. J. Educ. Technol. 2014, 45, 97-111. [CrossRef]

49. Tajfel, H. Human Groups and Social Categories: Studies in Social Psychology; Cambridge University Press: Cambridge, UK, 1981; p. 369.

50. Schau, H.J.; Gilly, M.C. We are what we post? Self-presentation in personal web space. J. Consum. Res. 2003, 30, 385-404. [CrossRef]

51. Short, J.; Williams, E.; Christie, B. The Social Psychology of Telecommunications; John Wiley: London, UK, 1976.

52. Li, G.; Liu, H.; Li, G. Payment willingness for VIP subscription in social networking sites. J. Bus. Res. 2014, 67, 2179-2184. [CrossRef]

53. Wang, H.Y.; Wang, S.H. Predicting mobile hotel reservation adoption: Insight from a perceived value standpoint. Int. J. Hosp. Manag. 2010, 29, 598-608. [CrossRef]

54. Heim, G.R.; Field, J.M. Process drivers of e-service quality: Analysis of data from an online rating site. J. Oper. Manag. 2007, 25, 962-984. [CrossRef]

55. Benlian, A.; Koufaris, M.; Hess, T. Service quality in software-as-a-service: Developing the SaaS-Qual measure and examining its role in usage continuance. J. Manag. Inf. Syst. 2011, 28, 85-126. [CrossRef]

56. Athanasopoulou, P. Relationship quality: A critical literature review and research agenda. Eur. J. Mark. 2009, 43, 583-610. [CrossRef]

57. Sanchez-Franco, M.J.; Ramos, A.F.V.; Velicia, F.A.M. The moderating effect of gender on relationship quality and loyalty toward Internet service providers. Inf. Manag. 2009, 46, 96-202. [CrossRef]

58. Xu, C.; Ryan, S.; Prybutok, V.; Wen, C. It is not for fun: An examination of social network site usage. Inf. Manag. 2012, 49, 210-217. [CrossRef]

59. Gustafsson, A.; Johnson, M.D.; Roos, I. The effects of customer satisfaction, relationship commitment dimensions, and triggers on customer retention. J. Mark. 2005, 69, 210-218. [CrossRef]

60. Chen, J.; Zhang, C.; $\mathrm{Xu}, \mathrm{Y}$. The role of mutual trust in building members' loyalty to a C2C platform provider. Int. J. Electron. Commer. 2009, 14, 147-171. [CrossRef]

61. Teo, T.S.; Srivastava, S.C.; Jiang, L. Trust and electronic government success: An empirical study. J. Manag. Inf. Syst. 2009, 25, 99-132. [CrossRef]

62. Zhou, T.; Li, H. Understanding mobile SNS continuance usage in China from the perspectives of social influence and privacy concern. Comput. Hum. Behav. 2014, 37, 283-289. [CrossRef]

63. Chiu, C.M.; Chiu, C.S.; Chang, H.C. Examining the integrated influence of fairness and quality on learners' satisfaction and Web-based learning continuance intention. Inf. Syst. J. 2007, 17, 271-287. [CrossRef]

64. Liang, T.-P.; Ho, Y.-T.; Li, Y.-W.; Turban, E. What drives social commerce: The role of social support and relationship quality. Int. J. Electron. Commer. 2011, 16, 69-90. [CrossRef]

65. Lin, H. Determinants of successful virtual communities: Contributions from system characteristics and social factors. Inf. Manag. 2008, 45, 522-527. [CrossRef]

66. Lin, H.; Fan, W.; Wallace, L. The effects of social and technical factors on user satisfaction, sense of belonging and knowledge community usage. Int. J. E-Collab. 2013, 5, 13-30. [CrossRef]

67. Chu, S.; Kim, Y. Determinants of consumer engagement in electronic word-of-mouth in social networking sites. Int. J. Advert. 2011, 30, 47-75. [CrossRef]

68. Yoon, C.; Rolland, E. Understanding continuance use in social networking services. J. Comput. Inf. Syst. 2015, 55, 1-9. [CrossRef]

69. Ellison, N.B.; Steinfield, C.; Lampe, C. Connecting strategies: Social capital implications of Facebook-enabled communication practices. New Media Soc. 2011, 13, 873-892. [CrossRef]

70. Nahapiet, J.; Ghoshal, S. Social capital, intellectual capital, and the organizational advantage. Acad. Manag. Rev. 1998, 23, 242-266. [CrossRef]

71. Lewicki., R.J.; Bunker, B.B. Developing and maintaining trust in work relationships. In Trust in Organizations; Kramer, R.M., Tyler, T.R., Eds.; Sage Publications: London, UK, 1996.

72. Putnam, R. Bowling alone: America's declining social capital. J. Democr. 1995, 6, 65-78. [CrossRef]

73. Leana, C.R.; Van Buren, H.J. Organizational social capital and employment practices. Acad. Manag. Rev. 1999, 24, 538-555. [CrossRef]

74. Wasko., M.; Faraj, S. It is what one does: Why people participate and help others in electronic communities of practice. J. Strateg. Inf. Syst. 2000, 9, 155-173. 
75. Wasko, M.M.; Faraj, S. Why should I share? Examining social capital and knowledge contribution in electronic networks of practice. MIS Q. 2005, 29, 35-57. [CrossRef]

76. Constant, D.; Sproull, L.; Kiesler, S. The kindness of strangers: The usefulness of electronic weak ties for technical advice. Organ. Sci. 1996, 7, 119-135. [CrossRef]

77. Jones, C.; Hesterly, W.S.; Borgatti, S.P. A general theory of network governance: Exchange conditions and social mechanisms. Acad. Manag. Rev. 1997, 22, 911-945. [CrossRef]

78. Lakhani, K.; von Hippei, E. How open source software works: Free' user-to-user assistance. Res. Policy 2003, 32, 923-943. [CrossRef]

79. Shiau, W.; Chau, P. Does altruism matter on online group buying perspectives from egotistic and altruistic behavior. In Proceedings of the PACIS, Jeju Island, Korea, 18-22 June 2013; p. 229.

80. Chen, K.K. Plan your burn, burn your plan: How decentralization, storytelling, and communication can support participatory practices. Sociol. Q. 2016, 57, 71-97. [CrossRef]

81. Osterloh, M.; Frey, B. Motivation, knowledge transfer, and organization forms. Organ. Sci. 2000, 11, 538-550. [CrossRef]

82. Kwon, O.B.; Wen, Y. An empirical study of the factors affecting social network service use. Comput. Hum. Behav. 2010, 26, 254-263. [CrossRef]

83. Kollock, P. The economies of online cooperation: Gifts, and public goods in cyberspace. In Communities in Cyberspace; Smith, M.A., Kollock, P., Eds.; Routledge: New York, NY, USA, 1999; pp. 220-239.

84. Agarwal, R.; Prasad, J.Y. A conceptual and operational definition of personal innovativeness in the domain of information technology. Inf. Syst. Res. 1998, 9, 204-215. [CrossRef]

85. Rogers, E.M. Diffusion of Innovations, 5th ed.; Free Press: New York, NY, USA, 2003.

86. Moore, G.; Benbasat, I. Development of an instrument to measure the perceptions of adopting an information technology innovation. Inf. Syst. Res. 1991, 2, 192-221. [CrossRef]

87. Cialdini, R.B.; Goldstein, N.J. Social influence: Compliance and conformity. Annu. Rev. Psychol. 2004, 55, 591-621. [CrossRef]

88. Huang, Q.; Davison, R.M.; Liu, H. An exploratory study of buyers' participation intentions in reputation systems: The relationship quality perspective. Inf. Manag. 2014, 51, 952-963. [CrossRef]

89. Koniordos, S.M. (Ed.) Networks, Trust and Social Capital: Theoretical and Empirical Investigations from Europe; Routledge: New York, NY, USA, 2017.

90. Zhou, Z.; Fang, Y.; Vogel, D.R.; Jin, X.L.; Zhang, X. Attracted to or locked in? Predicting continuance intention in social virtual world services. J. Manag. Inf. Syst. 2012, 29, 273-306. [CrossRef]

91. Ji, Y.G.; Hwangbo, H.; Yi, J.S.; Rau, P.L.; Fang, X.; Ling, C. The influence of cultural differences on the use of social network service and the formation of social capital. Int. J. Hum. Comput. Interact. 2010, 21, 1100-1121. [CrossRef]

92. Humberd, B.L.; Rouse, E.D. Seeing you in me and me in you: Personal identification in the phases of mentoring relationships. Acad. Manag. Rev. 2016, 41, 435-455. [CrossRef]

93. Ragins, B.R. Relational mentoring: A positive approach to mentoring at work. In The Oxford Handbook of Positive Organizational Scholarship; Cameron, K., Spreitzer, G., Eds.; Oxford University Press: New York, NY, USA, 2012; pp. 519-536.

94. Clement, R.; Noels, K.; Doeneault, B. Interethnic contact, identity, and psychological adjustments in the mediating and moderating roles of communication. J. Soc. Issues 2001, 57, 559-577. [CrossRef]

95. Song, J.; Kim, Y. Social influence process in the acceptance of a virtual community service. Inf. Syst. Front. 2006, 8, 241-252. [CrossRef]

96. Norris, P. The bridging and bonding role of on-line communities. Press/Politics 2002, 7, 3-13.

97. Steinfield, C.; Ellison, N.B.; Lampe, C. Social capital, self-esteem, and use of online social network sites: A longitudinal analysis. J. Appl. Dev. Psychol. 2008, 29, 434-445. [CrossRef]

98. Martínez-López, F.J.; Anaya-Sánchez, R.; Molinillo, S.; Aguilar-Illescas, R.; Esteban-Millat, I. Consumer engagement in an online brand community. Electron. Commer. Res. Appl. 2017, 23, 24-37. [CrossRef]

99. Dominick, J.R. Who do you think you are? Personal home pages and self-presentation on the world wide web. Journal. Mass Commun. Q. 1999, 76, 646-658. [CrossRef]

100. Hoffman, D.L.; Novak, T.P. Marketing in hypermedia computer-mediated environments: Conceptual foundations. J. Mark. 1996, 60, 50-68. [CrossRef] 
101. Cyr, D.; Hassanein, K.; Head, M.; Ivanov, A. The role of social presence in establishing loyalty in e-service environment. Interact. Comput. 2007, 19, 43-56. [CrossRef]

102. Hassanein, K.; Head, M. Manipulating perceived social presence through the web interface and its impact on attitude towards online shopping. Int. J. Hum. Comput. Stud. 2007, 65, 689-708. [CrossRef]

103. Zhang, L.; Zhu, J.; Liu, Q. A meta-analysis of mobile commerce adoption and the moderating effect of culture. Comput. Hum. Behav. 2012, 28, 1902-1911. [CrossRef]

104. Chai, S.; Kim, M. What makes bloggers share knowledge? An investigation on the role of trust. Int. J. Inf. Manag. 2010, 30, 408-415. [CrossRef]

105. Hsu, M.-H.; Ju, T.L.; Yen, C.-H.; Chang, C.-M. Knowledge sharing behavior in virtual communities: The relationship between trust, self-efficacy, and outcome expectations. Int. J. Hum. Comput. Stud. 2007, 65, 153-169. [CrossRef]

106. Fang, Y.; Chiu, C. In justice we trust: Exploring knowledge-sharing continuance intention in virtual communities of practice. Comput. Hum. Behav. 2010, 26, 235-246. [CrossRef]

107. Chiu, C.M.; Huang, H.Y.; Yen, C.H. Antecedents of trust in online auctions. Electron. Commer. Res. Appl. 2010, 9, 148-159. [CrossRef]

108. Shabbir, H.; Palihawadana, D.; Thwaites, D. Determining the antecedents and consequences of donor-perceived relationship quality-A dimensional qualitative research approach. Psychol. Mark. 2007, 24, 271-293. [CrossRef]

109. Lin, H.; Wang, Y. An examination of processes and consumer evaluations in product usage. J. Bus. Res. 1985, 13, 235-246.

110. Davis, F.D. Perceived usefulness, perceived ease of use, and user acceptance of information technology. Mis Q. 1989, 13, 319-339. [CrossRef]

111. Lin, C.A.; Jeffer, L.W. Factors influencing the adoption of multimedia cable technology. J. Mass Commun. Q. 1998, 75, 341-352. [CrossRef]

112. Bearden, W.O.; Rose, R.L. Attention to social comparison information: An individual difference factor affecting consumer conformity. J. Consum. Res. 1990, 16, 461-471. [CrossRef]

113. Kohli, A.K.; Jaworski, B.J. The influence of coworker feedback on salespeople. J. Mark. 1994, 58, 82-94. [CrossRef]

114. Solomon, D.; Knobloch, L. Information seeking beyond initial interaction. Hum. Commun. Res. 2002, 28, 243-257.

115. Kraut, R.; Patterson, M.; Lundmark, V.; Kiesler, S.; Mukopadhyay, T.; Scherlis, W. Internet paradox: A social technology that reduces social involvement and psychological well-being? Am. Psychol. 1998, 53, 1017-1031. [CrossRef]

116. McKenna, K.; Green, A.; Gleason, M. Relationship formation on the internet: What's the big attraction? J. Soc. Issues 2002, 58, 9-31. [CrossRef]

117. Uslaner, E.M. Social capital and the Net. Commun. Acm 2000, 43, 60-64. [CrossRef]

118. Brown, J.; Reingen, P. Social ties and word-of-mouth referral behavior. J. Consum. Res. 1987, 14, 350-362. [CrossRef]

119. Norman, A.; Russell, C. The pass-along effect: Investigating word-of-mouth effects on online survey procedures. J. Comput. -Mediat. Commun. 2006, 11, 1085-1103. [CrossRef]

120. Aragon, S.R. Creating social presence in online environments. New Dir. Adult Contin. Educ. 2003, 100, 57-68. [CrossRef]

121. Fortin, D.R.; Dholakia, R.R. Interactivity and Vividness Effects on Social Presence and Involvement with a Web-Based Advertisement. J. Bus. Res. 2005, 58, 387-396. [CrossRef]

122. Koufaris, M.; Hampton, S. The development of initial trust in an online company by new customers. Inf. Manag. 2004, 41, 377-397. [CrossRef]

123. Te'eni, D. Review: A cognitive-affective model of organizational communication for design IT. MIS Q. 2001, 25, 251-312. [CrossRef]

124. Jarvenpaa, S.L.; Tractinsky, N.; Vitale, M. Consumer Trust in an Internet Store. Inf. Technol. Manag. 2000, 1, 45-71. [CrossRef]

125. Collier, J.E.; Bienstock, C.C. Measuring service quality in e-retailing. J. Serv. Res. 2006, 8, 260-275. [CrossRef]

126. De Wulf, F.; Schillewaert, N.; Muylle, S.; Rangarajan, D. The role of pleasure in website success. Inf. Manag. 2006, 43, 434-446. [CrossRef] 
127. Ducoffe, R.H. Advertising value and advertising on the web. J. Advert. Res. 1996, 36, 21-36.

128. Fishbein, M.; Ajzen, L. Belief, Attitude, Intention, and Behavior: An Introduction to Theory and Research Reading; Addison-Wesley: Boston, MA, USA, 1975.

129. Schnake, M.E.; Dumler, M.P.; Cochran, D.S., Jr.; Barnett, T.R. Effects of differences in superior and subordinate perceptions of superiors' communication practices. J. Bus. Commun. 1990, 27, 37-50. [CrossRef]

130. Liu, H.; Maes, P.; Davenport, G. Unraveling the taste fabric of social networks. Int. J. Semant. Web Inf. Syst. 2006, 2, 42-71. [CrossRef]

131. Ha, S.; Stoel, L. Consumer e-shopping acceptance: Antecedents in a technology acceptance model. J. Bus. Res. 2009, 62, 565-571. [CrossRef]

132. Thong, J.Y.L.; Hong, S.J.; Tam, K.Y. The effects of post-adoption beliefs on the expectation-confirmation model for information technology continuance. Int. J. Hum. Comput. Stud. 2006, 64, 799-810. [CrossRef]

133. Hair, J.F.; Anderson, R.E.; Tatham, R.L.; Grablowsky, B.J. Multivariate Data Analysis; PPC Books: Tulsa, OK, USA, 1979.

134. Nunnally, J.C. Psychometric Theory; McGraw-Hill: New York, NY, USA, 1978.

135. Anderson, J.; Gerbing, D. Structural equation modeling in practice: A review and recommended two-step approach. Psychol. Bull. 1988, 103, 411-423. [CrossRef]

(C) 2020 by the authors. Licensee MDPI, Basel, Switzerland. This article is an open access article distributed under the terms and conditions of the Creative Commons Attribution (CC BY) license (http://creativecommons.org/licenses/by/4.0/). 